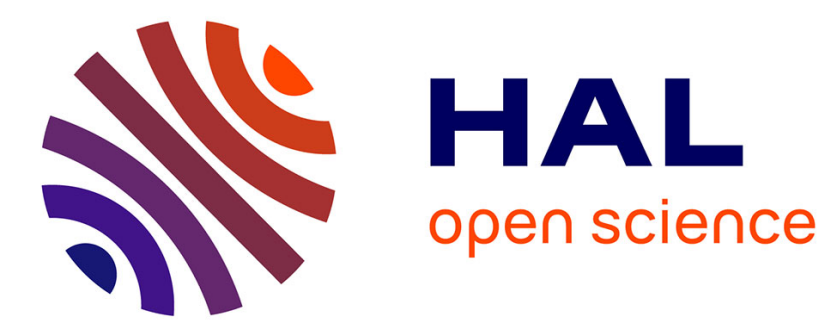

\title{
Microalgae as second generation biofuel. A review
}

Nirbhay Singh, Dolly Dhar

\section{To cite this version:}

Nirbhay Singh, Dolly Dhar. Microalgae as second generation biofuel. A review. Agronomy for Sustainable Development, 2011, 31 (4), pp.605-629. 10.1007/s13593-011-0018-0 . hal-00930486

\section{HAL Id: hal-00930486 https://hal.science/hal-00930486}

Submitted on 1 Jan 2011

HAL is a multi-disciplinary open access archive for the deposit and dissemination of scientific research documents, whether they are published or not. The documents may come from teaching and research institutions in France or abroad, or from public or private research centers.
L'archive ouverte pluridisciplinaire HAL, est destinée au dépôt et à la diffusion de documents scientifiques de niveau recherche, publiés ou non, émanant des établissements d'enseignement et de recherche français ou étrangers, des laboratoires publics ou privés. 


\title{
Microalgae as second generation biofuel. A review
}

\author{
Nirbhay Kumar Singh • Dolly Wattal Dhar
}

Accepted: 8 October 2010 / Published online: 11 March 2011

(C) INRA and Springer Science+Business Media B.V. 2011

\begin{abstract}
Microalgae are autotrophic microorganisms having extremely high photosynthetic efficiency and are valued as rich source of lipids, hydrocarbons, and other complex oils for biodiesel besides being an invaluable source of bioethanol, biomethane, and biohydrogen. Biodiesel produced from oilseed crops such as jatropha and soy have lower yields per unit land area and threaten food security. Indeed, microalgae have higher oil yields amounting to about 40 times more oil per unit area of land in comparison to terrestrial oilseed crops such as soy and canola. Further, microalgae production does not require arable land for cultivation. Biofuel is regarded as a proven clean energy source and several entrepreneurs are attempting to commercialize this renewable source. Technology for producing and using biofuel has been known for several years and is frequently modified and upgraded. In view of this, a review is presented on microalgae as second generation biofuel. Microalgal farming for biomass production is the biggest challenge and opportunity for the biofuel industry. These are considered to be more efficient in converting solar energy into chemical energy and are amongst the most efficient photosynthetic plants on earth. Microalgae have simple cellular structure, a lipid-rich
\end{abstract}

N. K. Singh $(\bowtie)$

Department of Microbiology,

C.P. College of Agriculture, S.D.A.U.,

S.K. Nagar, Gujarat 385506, India

e-mail: nirbhaysingh78@gmail.com

D. W. Dhar

Centre for Conservation and Utilisation of Blue Green Algae

(CCUBGA), IARI,

New Delhi 110012, India

e-mail: dollywattaldhar@yahoo.com composition, and a rapid rate of reproduction. Many microalgal strains can be grown in saltwater and other harsh conditions. Some autotrophic microalgae can also be converted to heterotrophic ones to accumulate high quality oils using organic carbon. However, there are several technical challenges that need to be addressed to make microalgal biofuel profitable. The efficiency of microalgal biomass production is highly influenced by environmental conditions, e.g., light of proper intensity and wavelength, temperature, $\mathrm{CO}_{2}$ concentration, nutrient composition, salinities and mixing conditions, and by the choice of cultivation systems: open versus closed pond systems, photobioreactors. Currently, microalgae for commercial purpose are grown mostly in open circular/elongated "raceway" ponds which generally have low yields and high production costs. However, a hybrid system combining closed photobioreactor and open pond is a better option. The biggest hurdle in commercialization of microalgal biofuel is the high cost and energy requirement for the microalgal biomass production, particularly agitation, harvesting, and drying of biomass. In order to conserve energy and reduce costs, algae are often harvested in a two-step process involving flocculation followed by centrifugation, filtration, or micro-straining to get a solid concentration. However, the major bottlenecks in algal biodiesel production within the cell can be identified and handled by adopting a system approach involving transcriptomics, proteomics, and metabolomics. Research and developments in the field of new materials and advanced designs for cultivation in closed bioreactors, use of waste water for biomass production, screening of efficient strains, high-value coproduct strategy, and cutting-edge metabolic engineering are thought to provide the biggest opportunities to substantially improve the cost effectiveness of such production systems. 
Keywords Bioactive compounds · Biodiesel - Bioethanol . Biohydrogen · Biomethane - Microalgae · Photobioreactors . Wastewater treatment

\section{Contents}

1. Introduction. . . . . . . . . . . . . . . . . 2

2. Microalgal second generation biofuel systems. . . . .3

3. Microalgal biofuel history . . . . . . . . . . . . .4

4. Microalgal biodiesel potential . . . . . . . . . . 4 4

4.1. Autotrophic microalgae . . . . . . . . . . . 5

4.2. Heterotrophic microalgae . . . . . . . . . . 5

5. Environmental condition for microalgal biomass production . . . . . . . . . . . . . . . . 5

5.1. Light . . . . . . . . . . . . 6

5.2. Temperature . . . . . . . . . . . 6

5.3. Gas exchange ...............6 6

5.4. Nutrients . . . . . . . . . . . . . . 6

5.5. Contamination . . . . . . . . . . . . 7

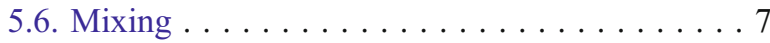

6. Culture techniques ................. 7

6.1. Open pond culture . . . . . . . . . . 7

6.2. Photobioreactors . . . . . . . . . . . 8 8

6.3. Fermenters . . . . . . . . . . . . 8 8

7. Harvesting of microalgal biomass . . . . . . 8

7.1. Flocculation . . . . . . . . . . . . .9

7.2. Centrifugation . . . . . . . . . . . 9

7.3 Filtration . . . . . . . . . . . . . .99

8. Microalgal biomass to biofuels ........... 9

8.1. Biodiesel . . . . . . . . . . . . . . . . .99

8.2. Bioethanol . . . . . . . . . . . . . . 10

8.3. Biomethane . . . . . . . . . . . . . . . . 10

8.4 Biohydrogen . . . . . . . . . . . . . 13

9. Enhancing cost-effectiveness of microalgal biofuels . . 13

9.1. Efficient strain selection and microalgal response

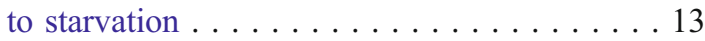

9.2. Metabolic engineering . . . . . . . . . 13 9.2.1. Genetic engineering to improve algal productivity . . . . . . . . . . 14

9.2.2. Biosynthesis of quality lipids . . . . . 15

9.2.3. Increasing the proportion of monounsatu-

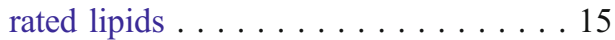

9.3. High-value coproduct strategy . . . . . . . . 17

9.4. Cost-effective technologies for biomass harvesting and drying . . . . . . . . . . . 17

9.5. Microalgal production along with wastewater treatment . . . . . . . . . . . . . . 18

10. Conclusions . . . . . . . . . . . . . . . . 18

11. Acknowledgement . . . . . . . . . . . . . . 18

12. References ..................... . 19

\section{Introduction}

Microalgae are photosynthetic cell factories, microscopic in nature, have high surface area-to-volume ratio, and are primary synthesizers of organic matter in aquatic habitats. It comprises a vast group of simple single-celled organisms that occur as discrete individuals alone, in pairs, in clusters, or in sheets of individuals all looking alike; but cannot form roots, stems, or leaves. The most abundant microalgae are single-cell drifters in plankton, generally called phytoplankton. They are capable of rapid uptake of nutrients and $\mathrm{CO}_{2}$, possess faster cell growth and have much higher photosynthetic efficiency than most of the land-based plants. Since ancient time, microalgae have been used in human health food products (Kim 1990; Khan et al. 2005), feeds for fish and livestock (Duerr et al. 1998; Becker 2007), and have been cultured for their high-value oils (Belarbi et al. 2000; Molina Grima et al. 2003; Wen and Chen 2003; Spolaore et al. 2006), chemicals, pharmaceutical products (Guerin et al. 2003; Pulz and Gross 2004; Spolaore et al. 2006), and pigments (Pulz and Gross 2004; Spolaore et al. 2006). Microalgae can provide diverse forms of renewable biofuels including biomethane (by anaerobic digestion of the algal biomass), biodiesel (from microalgal oil), bioethanol (by fermentation of the microalgal carbohydrates), and photobiologically produced biohydrogen (Akkerman et al. 2002; Banerjee et al. 2002; Gavrilescu and Chisti 2005; Kapdan and Kargi 2006; Ragauskas et al. 2006; Spolaore et al. 2006; Huntley and Redalje 2007; Dismukes et al. 2008).

The term "renewable" in this article refers to bioenergy, i.e., the energy coming from biomass, the supply of which is limited and their availability depends on the primary natural resources (e.g., lands, water, ecosystems, etc.). The word "biofuel" refers to the origin of the energy converted through the metabolism of living organisms with, at the basis of the food chain, autotrophic organisms converting solar energy into chemical energy contained in the molecules they produce via photosynthesis. Biofuels are a wide range of fuels which are in some way derived from biomass. However, biomass, in the energy sector, refers to biological material which can be used as fuel for transport, or an energy source to produce industrial or domestic heat and electricity (feedstock) (Bessou et al. 2010). The concept of using microalgal biomass as a potential source of biofuel is not new, but it is now being taken seriously because of the escalating petroleum prices and more significantly, the emerging concern about global warming and climate change which is more significantly associated with burning fossil fuels (Nagle and Lemke 1990; Sawayama et al. 1995; Gavrilescu and Chisti 2005). A conceptual model for integrated microalgal biomass and biofuel (biomethane, biodiesel, biohydrogen, and biogas) production is shown in Fig. 1. 
Fig. 1 A conceptual model for integrated microalgal biomass and biofuel production

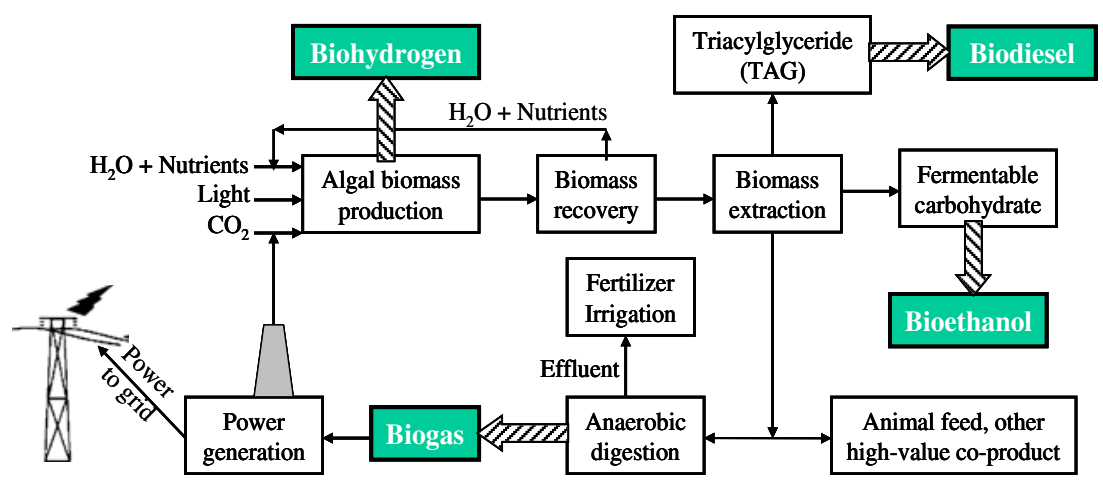

Currently, biodiesel is produced commercially from soybeans, canola oil, palm oil, corn oil, waste cooking oil, and jatropha oil, but not from microalgae (Barnwal and Sharma 2005; Felizardo et al. 2006; Kulkarni and Dalai 2006). The matter of concern is that these sources of biofuel are not sustainable in long term (Patzek and Pimentel 2005) as the sources currently used are either food/feed crops or tree crops. The food crops are not suitable for biofuel because of rising feeding requirements of the booming world population. The crop plants have a comparatively low potential and are usually harvested once or twice a year. The tree crops like Jatropha and Pongamia, presently used in several parts of the world, require 4-5 years to come to fruiting. Moreover, these require much more area for production of the same amount of biofuel as compared to microalgae.

This tendency is likely to change because biodiesel is a proven fuel and several entrepreneurs are attempting to commercialize microalgal biodiesel. Technology for producing and using biodiesel has been known for many years and it is noteworthy to mention that the high quality oil produced by these microalgae can be converted to biofuel using the existing technology (Barnwal and Sharma 2005; Demirbas 2005; Van Gerpen 2005; Felizardo et al. 2006; Kulkarni and Dalai 2006; Meher et al. 2006; Chisti 2007). Biofuels produced from microalgae have the potential to replace a portion of fossil fuel consumption with a renewable alternative. Previous research in the early 1990s by the National Renewable Energy Laboratory showed that under controlled conditions algae are capable of producing 40 times the amount of oil for biodiesel per unit area of land, compared to terrestrial oilseed crops such as soy and canola (Sheehan et al. 1998).

\section{Microalgal second generation biofuel systems}

A model second-generation biofuel system should have much higher net energy balance, should be more water efficient and should require much less arable land. A range of secondgeneration microalgae-based biofuel production systems are now under development (Kruse et al. 2005; Hankamer et al. 2007). Microalgae are reported to produce 15-300 times more oil for biodiesel production than traditional crops on area basis (Chisti 2007). Microalgae have a very short harvesting cycle $(\approx 1-10$ days depending on the process) allowing multiple or continuous harvests with significantly increased yields (Table 1; Schenk et al. 2008). Higher photosynthetic efficiency ultimately leads to reduced fertilizer and nutrient inputs, thereby, resulting in less waste and pollution.

Microalgal cultivation for biofuel production can potentially be carried out on marginal land and thus, can reduce the competition for land and may open up new economic opportunities for these arid, drought or salinity-affected regions (Schenk et al. 2008). Moreover, good amount of fresh water can be saved if closed bioreactor systems are used for algal cultivation especially using marine and halophilic strains of microalgae. The microalgal biomass generated in bioreactors can also be gasified or pyrolysed to produce a range of biofuels and can act as a complement in $\mathrm{CO}_{2}$ sequestration strategy (Weissman and Tillett 1992; Zeiler et al. 1995). In this way, transgenic organism's wastes can also be effectively disposed off in an environmentally sensitive way. The carbon-rich biomass pellets can also be stored as part of a carbon sequestration strategy which could utilize $\mathrm{CO}_{2}$ from power plants as an input for biomass production (Bridgwater and Maniatis 2004).

Other significant aspects of second generation microalgal systems are that they are amenable to highly innovative biotechnology approaches that have the potential for rapid improvements of algal strains and promise increase in yield by metabolic engineering (Sheehan et al. 1998; Ratledge 2004; Mussgnug et al. 2007). Although salt stress has been shown to play a role in oil production, freshwater species can undergo a stress response at osmolarities well below those of seawater, which can be strongly inhibitory or lethal (Vazquez-Duhalt and Arredondo-Vega 1991a, b; Takagi and Karseno 2006; Ranga et al. 2007). Several interesting findings have been obtained regarding osmo-adaptation in microalgae and the genes that exhibit anti-salt activity in microalgae (Kirst 
Table 1 Biodiesel production efficiency of plant oils and microalgae

\begin{tabular}{|c|c|c|c|c|}
\hline Plant source & $\begin{array}{l}\text { Biodiesel (L/ } \\
\text { ha/year) }\end{array}$ & $\begin{array}{l}\text { Area to produce global oil demand } \\
\text { (hectares } \times 10^{6} \text { ) }\end{array}$ & $\begin{array}{l}\text { Area required as percent } \\
\text { global land mass }\end{array}$ & $\begin{array}{l}\text { Area as percent global } \\
\text { arable land }\end{array}$ \\
\hline Cotton & 325 & 15,002 & 100.7 & 756.9 \\
\hline Soybean & 446 & 10,932 & 73.4 & 551.6 \\
\hline Mustard seed & 572 & 8,524 & 57.2 & 430.1 \\
\hline Sunflower & 952 & 5,121 & 34.4 & 258.4 \\
\hline Rapeseed/canola & 1,190 & 4,097 & 27.5 & 206.7 \\
\hline Jatropha & 1,892 & 2,577 & 17.3 & 130 \\
\hline Oil palm & 5,950 & 819 & 5.5 & 41.3 \\
\hline $\begin{array}{l}\text { Algae }\left(10 \mathrm{gm}^{-2} \text { day }^{-1} \text { at } 30 \%\right. \\
\text { triacylglyceride })\end{array}$ & 12,000 & 406 & 2.7 & 20.5 \\
\hline $\begin{array}{l}\text { Algae }\left(50 \mathrm{gm}^{-2} \text { day }^{-1} \text { at } 50 \%\right. \\
\text { triacylglyceride })\end{array}$ & 98,500 & 49 & 0.3 & 2.5 \\
\hline
\end{tabular}

1990; Galinski 1995; Tanaka et al. 2007). Often, these genes are generic anti-stress genes that likely act through alleviation of oxidative stress. Moreover, these microalgae exhibit increased photosynthetic efficiency and tolerance to grow in saline or wastewater streams (Aslan and Kapdan 2006; Singh and Dhar 2006, 2007; Shi et al. 2007).

\section{Microalgal biofuel history}

Renewable energy production from microalgae is not a new concept and has been carried out since last century. Early work on the anaerobic digestion of microalgae for producing methane fuel was carried out by Golueke et al. (1957). Microalgae are known to make far more efficient use of solar energy than conventional agriculture and therefore, there has a larger potential for biomass production with comparatively less land requirement (Benemann 2007). Oswald (1962) and Oswald et al. (1957) conducted experiments and concluded that the average algal biomass productivity was also much higher as compared to wheat. The most extensive research into the development of biofuels from algae was performed by the National Renewable Energy Laboratory (NREL) from 1978 to 1996 (Sheehan et al. 1998). It concluded that a more practical approach for near-term production of algal biodiesel is to utilize wastewater treatment for algae propagation, an already well-developed technology (Sheehan et al. 1998; Oswald 2003). Other analyses of full-scale algae to biodiesel production have been conducted by several workers (Benemann et al. 1982; Weissman and Goebel 1987; Chisti 2007). It is assumed that the economics of algae biodiesel will be achievable with improvements to algal biology through genetic and metabolic engineering, and the use of photobioreactors which can provide a controlled environment (Chisti 2007). On the other hand, some workers conclude that algae to biodiesel will have a large impact with combination of wastewater treatment in agreement with the NREL study (Benemann et al. 1982).

\section{Microalgal biodiesel potential}

Microalgae appear to be the only source of biodiesel that has the potential to completely displace fossil diesel, grow extremely rapidly and many are exceedingly rich in oil (Table 1). These commonly double their biomass within $24 \mathrm{~h}$ and during exponential growth, biomass doubling time may be as short as $3.5 \mathrm{~h}$. Microalgae with high oil productivities are desired for producing biodiesel and oil levels of 20-50\% are quite common (Table 2). Oil content in microalgae can exceed $80 \%$ by weight of dry biomass (Metting 1996; Spolaore et al. 2006). However, oil productivity (the mass of oil produced per unit volume of the microalgal broth per day) depends to a large extent on the algal growth rate and the oil content of the biomass.

Depending on species, microalgae produce many different kinds of lipids, hydrocarbons, and other complex oils (Banerjee et al. 2002; Metzger and Largeau 2005; Guschina and Harwood 2006). Not all algal oils are satisfactory for making biodiesel, but suitable oils do occur commonly. Moreover, production of algal oils requires an ability to inexpensively produce large quantities of oil-rich microalgal biomass. Potentially, instead of microalgae, oil producing heterotrophic microorganisms grown on a natural organic carbon source such as sugar, can be used to make biodiesel; however, heterotrophic production is not as efficient as using photosynthetic microalgae (Ratledge 1993; Ratledge and Wynn 2002). This is because the renewable organic carbon sources required for growing heterotrophic microorganisms are produced ultimately by photosynthesis, usually in crop plants. 
Table 2 Oil content of certain microalgae suitable for biodiesel production

\begin{tabular}{|c|c|c|}
\hline Microalga & Oil content ( $\%$ dry wt) & Reference \\
\hline B. braunii & $25-75$ & Chisti 2007 \\
\hline Chlorella emersonii & 63 & Illman et al. 2000 \\
\hline Chlorella minutissima & 57 & Illman et al. 2000 \\
\hline C. vulgaris & 56.6 & Liu et al. 2007 \\
\hline C. vulgaris & 40 & Illman et al. 2000 \\
\hline C. protothecoides & 23 & Illman et al. 2000 \\
\hline Chlorella sorokiniana & 22 & Illman et al. 2000 \\
\hline C. cohnii & 20 & Chisti 2007 \\
\hline Cylindrotheca $\mathrm{sp}$. & $16-37$ & Chisti 2007 \\
\hline D. primolecta & 23 & Chisti 2007 \\
\hline Isochrysis sp. & $25-33$ & Chisti 2007 \\
\hline M. salina & $>20$ & Chisti 2007 \\
\hline Monodus subterraneus & 39.3 & Khozin-Goldberg et al. 2006 \\
\hline Nannochloris sp. & $20-35$ & Chisti 2007 \\
\hline Nannochloropsis sp. & $31-68$ & Chisti 2007 \\
\hline N. oleoabundans & 54 & Metting 1996 \\
\hline N. oleoabundans & $35-54$ & Chisti 2007 \\
\hline Nitzschia laevis & 69.1 & Chen et al. $2008 \mathrm{~b}$ \\
\hline Nitzschia sp. & $45-47$ & Chisti 2007 \\
\hline Parietochloris incisa & 62 & Solovchenko et al. 2009 \\
\hline P. tricornutum & $20-30$ & Chisti 2007 \\
\hline Schizochytrium sp. & $50-77$ & Chisti 2007 \\
\hline T. sueica & $15-23$ & Chisti 2007 \\
\hline Chlorella sp. & $28-32$ & Chisti 2007 \\
\hline
\end{tabular}

\subsection{Autotrophic microalgae}

Autotrophic microalgae can utilize carbon dioxide as the carbon sources and sunlight as the energy source for oil accumulation under special conditions. It has been found that many autotrophic microalgae, such as Chlorella vulgaris, Botryococcus braunii, Navicula pelliculosa, Scenedesmus acutus, Crypthecodinium cohnii, Dunaliella primolecta, Monallanthus salina, Neochloris oleoabundans, Phaeodactylum tricornutum, and Tetraselmis sueica can accumulate oils (Liang et al. 2006; Chisti 2007). The microalgal biomass production and oil accumulation is influenced by a large number of factors and therefore, different species of microalgae vary widely in their ability of oil production. Apart from inherent potential of algal species, cultivation parameters, such as temperature, light intensity, $\mathrm{pH}$, salinity, mineral, and nitrogen sources, also influence oil production.

\subsection{Heterotrophic microalgae}

Some autotrophic microalgae can be converted to heterotrophic ones through changing cultivating conditions or using genetic engineering. Such microalgae also can accumulate high quality oils using organic carbon as the carbon source instead of using $\mathrm{CO}_{2}$ and sunlight (autotrophic mode of nutrition). For example, Chlorella protothecoides normally growing as autotrophic microalgae could use organic carbon sources for oil production and oil content in biomass was about four times than that in the corresponding autotrophic cells (Miao and Wu 2004). Some heterotrophic microalgae like Prototheca moriformis could even use cheap organic carbon sources for oil accumulation (Han et al. 2006). Generally, heterotrophic microalgae can easily be cultivated and controlled in normal fermenters. But, these require organic carbon sources for oil accumulation, which may limit the application of such microalgae for oil/biodiesel production to some extent.

\section{Environmental conditions for microalgae biomass production}

Successful microalgae cultivation requires specific environmental conditions, which vary from species to species. The major parameters influencing biomass production include light of proper intensity and wavelength, temperature, $\mathrm{CO}_{2}$ concentration, nutrient composition, salinities, and mixing conditions. 


\subsection{Light}

Being the basic energy source for phototrophic algae, the availability and intensity of light is one of the key parameters affecting the success or failure of algae cultures. The net growth of the algae culture at very low light intensities is zero (compensation point) (Lee 1997). With increase in light intensities, photosynthesis increases until a point is reached where the growth rate is the maximum attainable (saturation point) (Goldman 1979; Lee 1999; Richmond 2000). Increasing the light intensity beyond this point does not increase the growth rate and can lead to photo-oxidation, damaging the light receptors and thereby, decreasing the photosynthetic rate and productivity (photo inhibition).

The light-harvesting antennae of algal cells are extremely efficient and absorb all the light striking them even though it cannot all be used for photosynthesis. Thus, at high algal cell concentrations, almost all the available light is absorbed by a thin top layer of cells, leaving the rest in the dark (mutual shading). However, most algae get light saturated at about $20 \%$ of solar light intensities (Goldman 1979; Toreillo et al. 2003), hence, while the cells below the surface of the culture may be light limited, the cells in the top layer may face the opposite problems of light saturation and inhibition. The problem can be overcome by reducing the light path length of algae culture system to increase light penetration and increasing cell density to a point at which mutual shading minimizes the photoinhibition of algal cells. This is also facilitated by proper mixing which ensures that individual cells are not stationed exclusively in the dark or light zones of the culture as well as increasing mass transfer (Weissman and Goebel 1985; Grobbelaar 1994).

\subsection{Temperature}

Generally, rise in temperature leads to exponential increase in algal growth until an optimum level is reached, after which growth declines. For outdoor cultures and open systems, the ability to control temperatures is often limited and is determined by atmospheric temperature, solar irradiance, and humidity. Ambient temperature fluctuations can result in diurnal temperatures differences of as much as $20^{\circ} \mathrm{C}$ which can affect the productivity (Olaizola 2000; Borowitzka 2005).

Large water bodies have long response times to air temperatures and may suffer lack of synchronization between air temperature and optimal culture temperatures (Richmond 1987; Borowitzka 2005). Thus, this affects photosynthesis and creates a situation under which photo inhibition may occur during low levels of light intensity and sub-optimal temperatures ( $\mathrm{Lu}$ and Vonshak 1999;
Vonshak et al. 2001). Generally sustained temperatures above the optimal range may kill algal cells and temperatures below the optimal range may not, except for freezing conditions. Furthermore, biomass loss has been reported to increase at higher temperatures during dark periods (Weissman and Goebel 1985). Therefore, it is necessary to achieve optimal temperatures quickly in the morning and rapidly decreased temperatures after darkness, thereby, maintaining high productivity during the day and minimizing biomass loss at night.

\subsection{Gas exchange}

The low percentage of $\mathrm{CO}_{2}$ in the air $(0.033 \%)$ will quickly limit the growth if, supplementary carbon is not supplied as roughly $45-50 \%$ of algal biomass is made of carbon (Doucha et al. 2005; Chae et al. 2006). This $\mathrm{CO}_{2}$ is generally blended with air in aerated cultures or injected into the algal cultures via gas exchange vessels in photobioreactors or sumps in open raceways. Various methods adopted to reduce the losses of expensive $\mathrm{CO}_{2}$ in open algae cultures include bubbling through air stones, plastic dome exchangers with perforated pipes, injection into deep sumps, trapping the $\mathrm{CO}_{2}$ under floating gas exchangers, and maintaining high alkalinities in the culture water (Berzin 2005).

If oxygen concentrations exceed saturation level in algae cultures, photo-oxidative damage occurs to the chlorophyll reaction centers inhibiting photosynthesis and reducing productivity (Molina et al. 2001; Pulz 2001; Ugwu et al. 2007). Presence of an interface between the culture and the atmosphere in agitated cultures is not usually a problem as the $\mathrm{O}_{2}$ concentrations will remain similar to that of ambient air. However, in closed photobioreactors, additional facilities such as gas exchange chambers are required.

\subsection{Nutrients}

Nutrients supplied to algal cultures must include the inorganic elements that make up the algal cell besides macronutrients, vitamins, and trace elements. While there is limited reports on optimal levels of nutrients required for mass algal cultures, normally the macronutrients required are nitrogen and phosphorus (ratio $16 \mathrm{~N}: 1 \mathrm{P}$ ) and silicon (Brzezinski 1985; Harrison and Berges 2005). However, to avoid nutrient limitation, nutrients are usually added in excess and widely different ratios are used even when the same alga is cultured (Richmond 1999; Sanchez et al. 1999; Acien Fernandez et al. 2001).

Trace elements such as cobalt, copper, molybdenum, zinc, and nickel are considered effective in hydrogen production (Ramchandran and Mitsui 1984). Many of these metals have shown pronounced enhancement of hydrogen 
production which is thought to be due to their involvement in the nitrogenase enzyme activity. For example, Anabaena variabilis SPU003 is highly sensitive to copper, cobalt, manganese, zinc, nickel, and iron ions and shows no hydrogen production at concentrations below $10 \mathrm{mM}$ for these ions (Moezelaar et al. 1996). A culture of Anabaena cylindrica grown with $5.0 \mathrm{mg}$ of ferric ions/liter produce hydrogen at a rate about twice that of culture with $0.5 \mathrm{mg}$ of ferric ions/liter (Jeffries et al. 1978).

\subsection{Contamination}

The open pond system has a serious disadvantage of being susceptible to contamination by unwanted species if utmost care is not taken. A new open pond is typically inoculated with the desired strain of microalgae with the aim of initiating growth and dominating the pond flora. However, over time it is likely that some undesired species may inevitably be introduced and can severely reduce yields and even outcompete the inoculated species. If a significant competitor has taken residence in a pond, it is extremely difficult to eradicate (Schenk et al. 2008). However, cultures of microalgae are kept relatively pure by using culture medium that is specific to the organisms (Spolaore et al. 2006). Sustained and reliable cultivation of the desired species in open pond systems can be encouraged by cultivating extremophiles that tolerate and outcompete other species in a particular environment (e.g., high/low $\mathrm{pH}$ or salinity). A high bicarbonate concentration allows Spirulina to be grown in open ponds with few invasive algae and a high saline environment allows Dunaliella salina to be grown in "relative pure cultures" (Anderson 2005). Producers keep Chlorella cultures in pure conditions by use of large inoculum doses and by operating in short batches with harvesting done before major contamination can take place (Benemann 2008).

\subsection{Mixing}

At high algae concentrations, almost all the available light is absorbed only by a thin top layer of cells which can be avoided by proper mixing. Mixing must be sufficient enough to keep the algae cells in suspension and to provide uniform exposure of light to all the cells. Mixing also decreases the boundary layer around cells facilitating the increased uptake and exudation of metabolic products. In photobioreactors, mixing prevents sedimentation of the cells and supports distribution of $\mathrm{CO}_{2}$ and $\mathrm{O}_{2}$ (Molina Grima et al. 1999). For $\mathrm{CO}_{2}$, a partial pressure of at least $0.15 \mathrm{kPa}$ has to be maintained to prevent kinetic $\mathrm{CO}_{2}$ uptake limitation and a stoichiometric demand of $1.7 \mathrm{~g} \mathrm{CO}_{2}$ $\mathrm{g}^{-1}$ biomass has to be provided. This makes supply of $\mathrm{CO}_{2}$ purified from external flue gas (e.g., from a power plant) useful (Doucha et al. 2005). The rate of $\mathrm{CO}_{2}$ fixation in the crude extract of $50 \mathrm{~g}$ of thalli of a marine alga (Codium vermilara) was estimated to be $39 \mu$ moles $/ \mathrm{mg}$ chlorophyll ${ }^{-1} \mathrm{~h}$ and was constant for at least $15 \mathrm{~min}$ (Schonfeld et al. 1973). The light intensity required for saturation of photosynthesis in intact thalli of Codium when measured in the presence of $10 \mathrm{~mm} \mathrm{NaHCO} 3$ was found to be $5 \times 10^{4} \mathrm{erg} \mathrm{cm}^{-2} \mathrm{~s}^{-1}$, a value also markedly lower than that required for saturating photosynthesis in intact higher plants (Rabinowitch 1951). While light attenuation inside the reactor is not influenced by mixing, there is a complex interplay between culture mixing and light attenuation as each single algal cell passes through dark and light zones of the reactor in a more or less statistical manner (Barbosa et al. 2003).

\section{Culture techniques}

The choice of cultivation systems is an important aspect that significantly affects the efficiency and cost effectiveness of a microalgal biofuel production process (Lee 2001; Pulz 2001; Carvalho et al. 2006). A wide variation exists among the microalgal cultivation systems for the production of biomass. The three most widely used culture systems of raceways, photobioreactors, and fermenters have been discussed briefly.

\subsection{Open pond culture}

Large-scale cultivation of algae and cyanobacteria in outdoor open pond systems is well established (Benemann and Oswald 1996; Borowitzka 2005). Ponds can be excavated and used unlined or lined with impermeable materials or they can be built up with walls. Open ponds are suitable for a small number of algal species that can tolerate extreme environmental conditions to the exclusion of most other species. Such algal species include fast growers such as Chlorella, Spirulina, and Dunaliella which thrive in highly alkaline or saline environments (Chisti 2007).

Current technology envisages four main types of open ponds: (a) unmixed open ponds, (b) raceway ponds, (c) circular ponds, and (d) thin layer, inclined ponds. Unmixed open ponds are generally used for the mass culture of $D$. salina, have low productivities (less than $1 \mathrm{gm}^{-2} \mathrm{~d}^{-1}$ ) and are comparatively unsuitable for the culture of most algal species (Benemann and Oswald 1996; Borowitzka 2005). Whereas, raceway ponds are the most widely used open pond culture systems (Fig. 2; Chisti 2007) and are used frequently for the commercial cultivation of Spirulina, Haematococcus, and Dunaliella (Benemann and Oswald 1996). Circular ponds are mainly used in Asia for the production of Chlorella. It usually has provision of a centrally located rotating arm (similar to those used in wastewater treatment) for mixing 
and may have productivities ranging between $8.5 \mathrm{gm}^{-2} \mathrm{~d}^{-1}$ and $21 \mathrm{~g} \mathrm{~m}^{-2} \mathrm{~d}^{-1}$ (Benemann and Oswald 1996). However, thin layer, inclined ponds consist of slightly inclined shallow trays and may achieve productivities up to $31 \mathrm{gm}^{-2} \mathrm{~d}^{-1}$ (Doucha and Livansky 2006).

\subsection{Photobioreactors}

The problems associated with open systems including contamination, uncontrolled environments, evaporation, limited species suitability, low volumetric productivities, and the need for large land area have encouraged the development of closed (or mostly closed) photobioreactors in order to overcome inefficiency of the earlier systems. Several reports exist regarding the design, efficiency and cost-effectiveness of a microalgal biofuel production process (Lee 2001; Chisti 2007). Many closed systems in detail have also been explained by several workers (Carvalho et al. 2006; Schenk et al. 2008). Few open systems have been systematically compared with closed systems over different geographical regions (Lee 2001).

Even though the open pond systems seem to be favored for commercial cultivation of microalgae at present due to their low capital costs, closed systems offer better control over contamination, mass transfer, and other cultivation conditions. The combination of the closed photobioreactor and open pond combines the benefits of the two and has been demonstrated to be effective at a 2-ha scale (Huntley and Redalje 2007). Photobioreactors can be located indoors or outdoors depending upon the light collection and distribution systems and their commercial feasibility. Photobioreactors of diverse designs have been developed and patents have been awarded, e.g., tubular photobioreactors, vertical bubble columns and airlift reactors, combined bubble column and inclined tubular reactors, helical photobioreactors, and flat plate photobior-

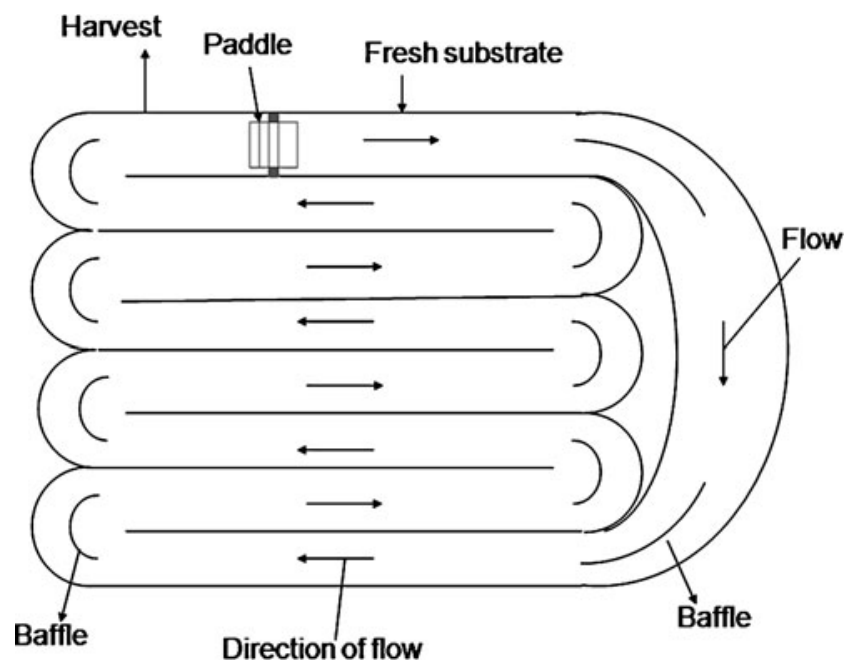

Fig. 2 Arial view of a raceway pond eactors (Tredici and Zittelli 1998; Sanchez et al. 1999; Berzin 2005; Ugwu et al. 2005).

\subsection{Fermenters}

While most algae grow phototrophically, some are capable of heterotrophic growth using organic substrates as the sole carbon and energy sources. This mode of algal cultivation is well established and has several advantages over phototrophic modes of growth (Barclay et al. 1994; Behrens and Kyle 1996). These include, the large existing fermentation technology knowledge base, high degree of process control for consistent reproducible production, elimination of light requirements, independence from weather and climatic conditions, and lower harvesting costs (Barclay et al. 1994; Ceron Garcia et al. 2000; Chen and Chen 2006). However, the heterotrophic cultivation of algae requires sufficient oxygen supply for catabolism of organic substrates (Moo-Young and Blanch 1987; Clark et al. 1995).

Generally, heterotrophic cultivation has been found to increase the total lipid content in algae compared to phototrophically grown cells (Miao and Wu 2006; Li et al. 2007). The heterotrophically grown Chlorella cells accumulated lipids to about $55.2 \%$ of the cellular dry weight as opposed to $14.6 \%$ in phototrophically grown cells (Miao and $\mathrm{Wu}$ 2006). Furthermore, heterotrophic cultivation of algae usually (but not always) results in higher yields (Wen and Chen 2000; Yu et al. 2009). For species that can utilize both light energy and chemical substrates, mixotrophic mode of cultivation offers a superior alternative to phototrophic and heterotrophic growth as both biomass and productivity increases have been reported (Fang et al. 2004; Yu et al. 2009). Productivities as high as $127 \mathrm{gm}^{-2} \mathrm{~d}^{-1}$ (daytime) and $79 \mathrm{gm}^{-2} \mathrm{~d}^{-1}$ (night time) have been reported for mixotrophic cultures of Chlorella in comparison to $35.8 \mathrm{gm}^{-1} \mathrm{~d}^{-1-} 41.4 \mathrm{~g}$ $\mathrm{m}^{-1} \mathrm{~d}^{-1}$ obtained in photosynthetic cultures (Borowitzka 1992; Lee and Low 1992).

\section{Harvesting of microalgal biomass}

Biomass harvesting cost can be a significant proportion of the total algal production cost and range between 3.3 and 30\% (Gudin and Therpenier 1986; Nakamura et al. 2005). This is because obtaining the algae biomass from the relatively dilute culture broths requires processing large volumes of water. In order to conserve energy and reduce costs, algae are often harvested in a two-step process. In the first step, the algae are concentrated, often by flocculation, which concentrates the dilute cultures to about $1-5 \%$ solids. In the second step, the cells are further concentrated by centrifugation, filtration, or micro-straining to get a solid concentration up to 25\% (Golueke and Oswald 1965; Shelef et al. 1984). 


\subsection{Flocculation}

Microalgae carry negative cell surface charges which when neutralized lead to the agglomeration of the biomass into large clumps or "flocs". These flocs can then be more readily separated from the culture medium (Tilton et al. 1972; Benemann and Oswald 1996). Flocculation can be induced in various ways like, chemical flocculation (inorganic chemicals), chemical flocculation (polyelectrolytes), bioflocculation, electroflocculation, and dissolved air floatation. Inorganic flocculants like $\mathrm{Al}_{2}(\mathrm{SO} 4)_{3}$ (alum), $\mathrm{Fe}_{2}(\mathrm{SO} 4)_{3}$ (ferric sulfate), $\mathrm{FeCl}_{3}$ (ferric chloride), or $\mathrm{Ca}$ $(\mathrm{OH})_{2}$ (lime) neutralize or reduce the negative surface charge of the cells causing the formation of flocs (Golueke and Oswald 1965; Sheehan et al. 1998; Heasman et al. 2000). However, it was concluded that chemical flocculation was too expensive for biofuels production and incorporation of large amount of metal salts in the harvested biomass limits its use and creates disposal problems (Sheehan et al. 1998; Molina Grima et al. 2003). Polymeric organic flocculants (polyelectrolytes) on the other hand are highly charged organic aggregates, non-toxic, required in small amounts, produce more stable flocs and thus, are more attractive flocculation option (Barclay et al. 1985; Sheehan et al. 1998).

Some algal species are reported to naturally flocculate after transfer to settling ponds when left quiescent for some time (Nakamura et al. 2005). This occurrence has been attributed to environmental stimuli, some of which have been identified, including nitrogen limitation, $\mathrm{pH}$, and dissolved oxygen level (Lee et al. 1998; Blanchemain and Grizeau 1999). Electroflocculation is a coagulation/flocculation process which is based on the movement of electrically charged particles in an electric field in which active coagulant species are produced by oxidation of a metal anode (Poelman et al. 1997). Dissolved air floatation involves pressurizing some of the liquid to dissolve additional air (Levin et al. 1961; Borodyanski and Konstantinov 2003).

\subsection{Centrifugation}

This is a well-established industrial process that uses gravitational force to achieve separation. The morphology and sizes of the cells being harvested affect the recovery (and costs) as filamentous cells and large colonial cells will settle more readily than single smaller cells (Nakamura et al. 2005). Centrifugation is energy intensive and the estimates of the energy consumption required for various types of centrifuges are estimated to range from 0.3 to $8 \mathrm{kWh} . \mathrm{m}^{3}$ (Molina Grima et al. 2003). The high capital and running costs associated with centrifuges limit their use to secondstage filtration in the processing of microalgae for biofuels.

\subsection{Filtration}

Filtration involves introducing the particles onto a screen of given aperture size. The particles either pass through or are retained on the screen according to their size. Filtration can be performed under pressure or vacuum with energy requirement estimates ranging from 0.2 to $0.88 \mathrm{kWh} \mathrm{m}^{3}$ and $0.1-5.9 \mathrm{kWh} \mathrm{m}^{3}$, respectively (Shelef et al. 1984; Molina Grima et al. 2003). Filtration can also be carried out by microstrainers consisting of a rotating drum covered by a straining fabric where a backwash spray collects the particles into an axial trough and requiring lower power consumption between 0.02 and $0.2 \mathrm{kWh} \mathrm{m}^{3}$ (Benemann et al. 1977; Shelef et al. 1984). Although, the costs associated with filtration are low, screen clogging and membrane fouling limits its suitability to larger species of microalgae.

\section{Microalgal biomass to biofuels}

For conversion of microalgal biomass to biofuel, numerous options exist. Approaches like open ponds, raceways, or photobioreactors have been adopted by a large number of companies and research organizations for large-scale production of microalgal biomass. Although production of biodiesel and the use of flue gas is the main approach chosen so far; bioethanol, biomethane, and biohydrogen are also the important bioenergies obtained from microalgae.

\subsection{Biodiesel}

All microalgal oils are not satisfactory for biodiesel production but suitable oils occur commonly and are known to produce many different kinds of lipids, hydrocarbons, and other complex oils (Banerjee et al. 2002; Guschina and Harwood 2006). On the basis of chemical characteristics, lipids are subdivided in two main classes, polar and nonpolar/neutral/simple lipids (Christie 2003). Neutral lipids include the tri-, di-, and monoglycerides; waxes; and isoprenoid-type lipids. However, polar lipids include phospholipids (e.g., phosphatidylinositol, phosphatidylcholine, phosphatidylethanolamine) and glycolipids (combinations of oligosaccharides and lipids; e.g., monogalactosyl diglyceride), esters of fatty acids, and glycerol. This distinction in the main lipid classes is important for the subsequent conversion of microalgal oils to biofuels, as the composition of the lipid feedstock affects the efficiency and yield of fuel conversion by catalytic routes.

To obtain microalgal oil, the algae are first concentrated and the oil is extracted, using an organic solvent $(90 \%$ oil 
recovery) or a filter press (75\% oil recovery) (Nagle and Lemke 1989). The residue contains starch and proteins and can be further processed to make ethanol, animal feed, or used as a feedstock in an anaerobic fermenter. Biodiesel production is a transesterification process involving transformation of highly viscous oils into alkyl esters with lower viscosity, similar to normal diesel fuel and glycerine (Fig. 3). Transesterification requires $3 \mathrm{~mol}$ of alcohol for each mole of triglyceride to produce $1 \mathrm{~mol}$ of glycerol and $3 \mathrm{~mol}$ of methyl esters. This reaction is reversible in nature and arrives at equilibrium at a certain stage (Fukuda et al. 2001).

The relative proportion of polar lipids to neutral lipids (triglycerides) and the high amount of long-chain polyunsaturated fatty acids (greater than C18) are common in microalgae but are not produced in significant quantities in higher plants. Both of these aspects affect the efficiency of biodiesel synthesis, as well as influence the fuel properties (e.g., very low oxidative stability of highly unsaturated fatty acids). In general, it appears that algal cells synthesize triglycerides at times when the energy input, through carbon assimilation, exceeds the immediate metabolic needs of the cell. The relative composition of microalgal lipids depends greatly on the species used and the nutrient, environmental, and developmental conditions in which the cells are cultured and harvested. It has been reported that the composition of microalgal lipids varies considerably with the growth cycle, under nutrient limitation and during a diurnal light dark cycle (Sukenik and Carmeli 1990; Ekman et al. 2007). For example, Nannochloropsis sp. accumulate triglycerides during the day and subsequently rapidly mobilize it in the dark to supply the energy needed for cell division (Sukenik et al. 1989). Triglycerides may serve as a sink for free fatty acids, to remove these from the cytoplasm and thereby avoiding lipotoxicity; they may act as energy and electron sinks during stress conditions (Roessler 1990; Kurat et al. 2006; Hu et al. 2008).

The physico-chemical properties of biodiesel (alkyl esters of fatty acid constituents of lipids) are largely determined by the structure of the constituent acyl chains (Knothe 2005). The most important fuel characteristics, according to the American Society for Testing and Materials (D6751-09 biodiesel standard), are ignition quality, cold-flow properties, and oxidative stability. Polyunsaturated fatty acids are more prone to oxidation and biodiesel made from these oils are not likely to meet the

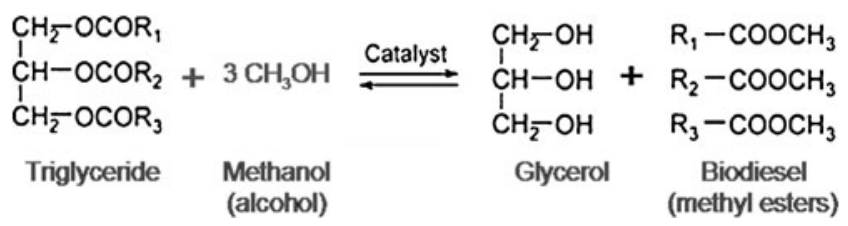

Fig. 3 Transesterification of triglyceride (oil) to biodiesel (methyl esters) international standards (Chisti 2007). Despite this, biodiesel produced from these oils has a lower melting point and thus, possess excellent cold flow properties compared to biodiesel from saturated fats (which tends to gel at ambient temperatures) (Hu et al. 2008; Schenk et al. 2008). To meet the biodiesel fuel quality standards, the extent of unsaturation in algal oils can be reduced by partial catalytic hydrogenation (Dijkstra 2006; Chisti 2007).

\subsection{Bioethanol}

The starch content of algae is reported to reach much higher values which are comparable to corn, wheat and other conventional ethanol feed stocks (Feinberg 1984; S and T 2003). Microalgae have high potentiality for bioethanol production; which may be because of their high rate of productivity, high fermentable carbohydrates content of the biomass and lack of lignin in comparison to the terrestrial feedstocks (Table 3; Moore 2009). The potential of microalgae can be judged by the fact that $75 \%$ of algal complex carbohydrates can be hydrolyzed into a fermentable hexose monomer and fermentation yield of ethanol is $80 \%$ of the theoretical value (Huntley and Redalje 2007). However, lignin, a recalcitrant substance (not easily degraded) present in the biomass, cannot be converted to bioethanol and its processing is a major impediment for bioethanol production (Ragauskas et al. 2006).

After oil extraction from the microalgal biomass, a fermentation process utilizing enzymes alpha-amylase and gluco-amylase and yeast for fermenting the sugars to ethanol and carbon dioxide has been devised (Dismukes et al. 2008). The fermented mash so resulting contains about $11-15 \%$ ethanol by volume as well as the nonfermentable solids from the algae and the yeast cells. Ethanol is distilled off the mash at $96 \%$ strength, while the residual stillage can be recovered from the base of the column and dried to obtain dried distiller's grain. Another interesting method of microalgal bioethanol production is demonstrated under dark and anaerobic conditions in which the starch within the cells of microalgae was fermented (Hirano et al. 1997). This essentially means that ethanol can be made within the microalgal cells. The potential for simple and low cost methods of bioethanol production are apparent. The next phase of this research should try to develop methods of improving the efficiency of this intracellular ethanol production.

\subsection{Biomethane}

Biogas production from microalgal biomass is a focus of interest as the efficiency of biomass production/ha is estimated to reach five to 30 times than that of crop plants and a major part of the methane demand can be satisfied 
Table 3 Differences in productivity, fermentable carbohydrate and lignin content in some bioethanol feed stocks (Moore 2009)

\begin{tabular}{llllll}
\hline Feedstock & $\begin{array}{l}\text { Productivity (dry Mg/ } \\
\text { ha/year) }\end{array}$ & $\begin{array}{l}\text { \% Fermentable } \\
\text { carbohydrate }\end{array}$ & \% Lignin & $\begin{array}{l}\text { Fermentable carbohydrate productivity } \\
\text { (dry Mg/ha/year) }\end{array}$ & $\begin{array}{l}\text { Lignin productivity } \\
(\text { dry Mg/ha/year) }\end{array}$ \\
\hline $\begin{array}{l}\text { Woody } \\
\text { biomass }\end{array}$ & $10-22^{\mathrm{a}}$ & $70-85^{\mathrm{f}}$ & $25-35^{\mathrm{f}}$ & $7-18.7$ & $4-7.7$ \\
$\begin{array}{l}\text { Switch } \\
\text { grass }\end{array}$ & $3.6-15^{\mathrm{b}}$ & $76.4^{\mathrm{f}}$ & $12^{\mathrm{f}}$ & $2.8-11.5$ & $0.4-1.8$ \\
$\begin{array}{l}\text { Corn } \\
\text { Chlorella } \text { sp }\end{array}$ & $6-14$ & $80-92^{\mathrm{f}, \mathrm{g}}$ & $15^{\mathrm{f}}$ & 5.6 & 1.05 \\
$\begin{array}{l}\text { T. sueica } \\
\text { Arthrospira }\end{array}$ & $38-139.4^{\mathrm{d}}$ & $33.4^{\mathrm{c}}$ & $0^{\mathrm{c}}$ & $42.7-87.8$ & 0 \\
sp & $27-70^{\mathrm{b}}$ & $11-47^{\mathrm{b}}$ & $0^{\mathrm{b}}$ & $4.2-65.5$ & 0 \\
\hline
\end{tabular}

\footnotetext{
${ }^{\text {a }}$ Ragauskas et al. 2006

${ }^{\mathrm{b}}$ Dismukes et al. 2008

${ }^{\mathrm{c}}$ Kristensen 1990

${ }^{\mathrm{d}}$ Zittelli et al. 2006

${ }^{\text {e }}$ Chisti 2007

${ }^{\mathrm{f}}$ Sanchez 2009

${ }^{\mathrm{g}}$ Zhu et al. 2007
}

with biogas (Sheehan et al. 1998). One of the first feasibility study using microalgae for biomethane production was published almost 50 years ago which concluded that the process could be feasible and could further be optimized (Golueke and Oswald 1959). Successful cultivation of microalgae requires huge quantities of nitrogen and phosphate for which environmental and economic impact may not be sustainable. It is therefore desirable to recycle the nitrogen and phosphorus contained in the microalgal waste after lipid extraction in order to reduce the use of fertilizers (Sialve et al. 2009). Such problem can effectively be handled by anaerobic digestion involving biotechnological approaches, which can mineralise algal waste containing organic nitrogen and phosphorus, resulting in a flux of ammonium and phosphate that can then be used again as a substrate for the microalgae (Olguin 2000; Phang et al. 2000). Chisti (2007) has also proposed that in order to reach an economical balance, the biomass obtained after lipid extraction needs to be transformed into methane. Therefore, algal waste after being processed by anaerobic digestion will not only recycle nitrogen and phosphorus but also produce methane.

The energetic value of the methane thus produced can potentially lead to an energetic balance of the microalgae to biofuel process (Sialve et al. 2009). Anaerobic degradation of phytoplanktonic cells is a process which takes place naturally in aquatic environments after algal cells sink in the anoxic and aphotic zones where they eventually die and break up. Nutrient remineralisation in these anoxic layers of aquatic environments is responsible for ammonium and phosphate release and hence recycling such important nutritive elements, which can eventually sustain growth of phytoplanktonic communities (Vandenbroucke and Largeau 2007).

For biomethane production, either a multispecific biomass is harvested from a wastewater treatment pond, or a monospecific biomass is grown in the laboratory (Asinari Di San Marzano et al. 1982; Chen 1987; Yen and Brune 2007). A significant enhancement of the methane production has been reported with addition of waste paper to algal sludge feedstock (Yen and Brune 2007). They reported a maximum methane production rate of $1.61 \mathrm{LL}^{-1} \mathrm{~d}^{-1}$ under mesophilic condition when the loading rate was $5 \mathrm{~g}$ VS L ${ }^{-1} \mathrm{~d}^{-1}$ when algal sludge was mixed with $60 \%$ of waste paper. Indeed, it was an indication of the increased cellulase activity stimulated by the specific nature of the waste paper. It appeared that the addition of waste paper had a positive effect on the digestion of algal cell walls and therefore on the anaerobic digestion itself. Moreover, codigestion led to the dilution of certain toxic compounds maintaining them under their toxic threshold. Theoretically, the higher the lipid content of the cell, the higher the potential methane yield. The high energetic content of lipids makes microalgae attractive substrates for anaerobic digestion due to their higher gas production potential compared with carbohydrates and proteins (Li et al. 2002; Cirne et al. 2007).

The hydraulic and solid retention time are key parameters in anaerobic processes. The hydraulic and solid retention time should be high enough to allow the active populations to remain in the reactor, especially methanogens, and not to limit hydrolysis which is generally 
regarded as the rate-limiting step in the overall conversion of complex substrates to methane. In the case of slowly degradable complex organic pollutants, hydraulic retention time is a deciding factor (Speece 1996). The methane yield remains maximal and constant when loading rate is low and hydraulic retention time is high. Moreover, optimal loading rates and hydraulic retention times must be chosen carefully for efficient conversion of organic matter, depending on the type/composition of the algal substrate. It is because, accessibility of the microalgal intracellular content to the anaerobic microflora is limited by the resistance of the microalgal cell wall to hydrolysis when the cells are directly injected into the anaerobic process (Asinari Di San Marzano et al. 1982; Chen 1987).

Regardless of the operating conditions and species, the proportion of methane in the biogas produced for the majority of the studies falls in the range $69-75 \%$. The quality of conversion of the microalgal organic matter into methane is also satisfactory. However, $\mathrm{pH}$ has been reported to be the most important factor impacting $\mathrm{CH}_{4}$ proportion in the biogas from algal biomass as it controls the speciation of the carbonate system and the release of $\mathrm{CO}_{2}$. At high $\mathrm{pH}$, due to high alkalinity from $\mathrm{NH}_{3}$ release, the gas content will shift more to $\mathrm{CH}_{4}$. The biogas quality is also affected by the oxidation state of the biomass, which drives the proportion of released methane (Sialve et al. 2009). However, due to less content of sulphurated amino acids, the microalgal biomass digestion releases a lower amount of hydrogen sulfide than other types of organic substrates (Becker 1988).

Anaerobic digestion of wastewater is a well-known technology and is widely used in agro-industrial processes such as dairy lagoons. The traditional wastewater treatment ponds can be modified by creating a controlled anaerobic environment such as a covered pond or tank which allows the methane to be captured and combusted for energy production. In the biochemical process of anaerobic digestion, the waste goes through three steps namely hydrolysis, fermentation and methanogenesis as it is converted to methane (Metcalf and Eddy 2003). Anaerobic digestion is a very effective process for biological oxygen demand removal but it is not an effective way to remove nutrients. Thus, there is a need for further treatment of the effluent from anaerobic digesters before it can be discharged into the environment. The relatively high lipid, starch, and protein contents and the absence of lignin make microalgae an ideal candidate for efficient biomethane production by fermentation in biogas plants. Similar to biodiesel, lipids play an important role since their conversion capacity into biomethane is higher $(1,390 \mathrm{~L}$ biogas $\mathrm{kg}^{-1}$ organic dry substance) than that of proteins and carbohydrates (VDI 2004). Using highly efficient closed algal bioreactors for biomass feedstock and bio- methane production, microalgae can now be grown in large amounts (150-300 t/ha/year; Pulz and Gross 2004; Chisti 2007). This quantity of biomass can theoretically yield 0.2 0.4 million $\mathrm{m}^{3}$ of methane/ha/year.

High protein and sodium (marine species) content are other significant factors that have the potentiality to affect the methane yield and productivity. High nitrogen concentrations in the microalgal biomass lead to the release of a significant amount of ammonia during anaerobic digestion, which accumulates in the liquid phase. At high biomass concentration in the influent; $\mathrm{NH}_{3}$ concentrations and the resultant alkalinity will increase and, as a consequence, inhibition of fermentation by free ammonia may occur (Mc Carty 1964). Samson and LeDuy (1986) reported that anaerobic digestion of Spirulina maxima (containing about $60 \%$ proteins on dry weight basis) releases an extremely high concentration of ammonia (up to $7,000 \mathrm{mg} / \mathrm{L}$ ). The methanogenic bacteria are probably among the most sensitive to high $\mathrm{NH}_{3}$ concentration (Angelidaki and Ahring 1993). The unionized hydrophobic form of nitrogen diffuses passively across the cell membranes where, it shows its toxicity and therefore inhibits the anaerobic microflora. This inhibition is affected by factors such as acclimation period, nature of substrate and inoculum, operating conditions, high ammonia concentration (1.7$\left.14 \mathrm{gL}^{-1}\right)$, and thermophilic condition. However, high concentrations of $\mathrm{Na}^{+}, \mathrm{Ca}^{2+}$, and $\mathrm{Mg}^{2+}$ increase the alkalinity and decrease the fraction of unionized $\mathrm{NH}_{3}$ and thus can lower the inhibition effects. Methanogenic bacteria also have the tendency to acclimatize to high ammonium concentration and therefore may increase the level of toxicity threshold (Chen et al. 2008a).

The anaerobic microorganisms require sodium only in trace quantity $(0.002-0.004 \mathrm{M})$ for their metabolism and are strongly inhibited at sodium concentration above 0.14 M (Mc Carty 1964; Kugelman and McCarty 1965; Rinzema et al. 1988). Marine microalgae have been reported to require a culture medium with high sodium chloride $(0.5-1 \mathrm{M})$. However, it is also reported that $\mathrm{NaCl}$ has no particular effect up to $0.3 \mathrm{M}$, at $0.4 \mathrm{M}$ the methane production becomes affected and it causes toxicity only above $0.5 \mathrm{M}$ (Chen 1987). Moreover, it is feasible to use salt-adapted microorganisms capable of withstanding high salinities through adaptation of the sludge to high salt concentrations (Chen et al. 2008a). There are sufficient evidences suggesting no inhibition of saline waste anaerobic digestion at concentrations close to marine water (Asinari Di San Marzano et al. 1982; Omil et al. 1995). Additionally, sodium turns out to be less inhibitory in mesophilic as compared to the thermophilic conditions. The potential toxicity of sodium is also affected by the presence and concentration of various cations $\left(\mathrm{Ca}^{2+}, \mathrm{Mg}^{2+}\right.$, and $\left.\mathrm{K}^{+}\right)$ (Chen et al. 2008a). However, the knowledge of the 
biological processes taking place in a biogas production facility is limited and therefore, more research in this field is needed to improve the biomethane production process.

\subsection{Biohydrogen}

A large number of unicellular, filamentous, fresh water, and marine cyanobacterial species and strains have been reported to produce large quantity of hydrogen (Fig. 4; Table 4). Gloeocapsa alpicola, A. variabilis, Anabaena azollae, Arthrospira (Spirulina) platensis, A. cylindrica, Cyanothece, Nostoc muscorum, etc. has been reported to produce a high quantity of hydrogen gas (Jeffries et al. 1978; Aoyama et al. 1997; Antal and Lindblad 2005). Anabaena sp. is reported to produce extraordinarily significant amount of hydrogen. Among them nitrogenstarved cells of $A$. cylindrica produces highest amount of hydrogen (30 ml $\mathrm{H}_{2} / \mathrm{lit} / \mathrm{h}$; Margheri et al. 1990).

These cyanobacterial strains use two sets of enzymes to generate hydrogen gas. The first one is nitrogenase and it is found in the heterocysts of filamentous cyanobacteria when they grow under nitrogen-limiting conditions. Hydrogen is produced as a by-product of fixation of nitrogen into ammonia. The reaction consumes 16ATP for fixation of $1 \mathrm{~mol}^{\text {of }} \mathrm{N}_{2}$ and results into formation of $1 \mathrm{~mol}$ of hydrogen gas.

The other hydrogen-metabolizing/producing enzymes in cyanobacteria are hydrogenases, which occur as two distinct types in different cyanobacterial species. The first one is uptake hydrogenase (encoded by hupSL) which has the ability to oxidize hydrogen in a reaction known as oxyhydrogenation or Knallgas reaction whereas, the other type of hydrogenase is reversible or bidirectional hydrogenase (encoded by hoxFUYH) having capacity to either take up or produce hydrogen (Schmitz et al. 1995; Tamagnini et al. 2002). Hydrogen is an important fuel and is widely applied in fuel cells, liquefaction of coal, upgrading of heavy oils, and several other operation. Hydrogen can be produced biologically by a variety of means, including the steam reformation of bio oils, dark and photo fermentation of organic materials, and photolysis of water catalyzed by special microalgal species (Kapdan and Kargi 2006; Ran et al. 2006; Wang et al. 2007).

\section{Enhancing cost-effectiveness of microalgal biofuels}

The biggest impediment in commercialization of microalgal biofuel is the high cost and energy requirement for the mass production of microalgae. Each and every part of the technology used during agitation, harvesting, and drying of biomass should be made more perfect so as to prevent excessive power expenditure. Moreover, efficient strain selection, metabolic engineering, utilization of waste water for biomass production, and high value coproduct strategy should be taken into consideration.

\subsection{Efficient strain selection and microalgal response to starvation}

Out of several different renewable fuels produced from microalgae, the desired end product is occasionally the primary factor influencing the choice of species and selection of strain. Other factors that should be considered during species selection include growth rate, optimal temperature range, lipid accumulation, and response to nutrient deprivation; as these factors affect the performance and productivity of the algae in the proposed culture system. Normally, lipid production of most oleaginous algae from various taxa is about $25 \%$ of the dry weight (Ben-Amote et al. 1985; Hu et al. 2008). However, under stress of nutrient deprivation, the cell division stops while the cells continue to accumulate storage products at about the same rate. This result in the accumulation of neutral lipids (including hydrocarbons) and increase in the percentage of lipids to around 35-45\% (Benemann and Oswald 1996; Sheehan et al. 1998).

The responses of different algae (in terms of their storage product) to nutrient deprivation are variable; therefore, this method can be adapted for the generation of desired storage product (Opute 1974). For instance, while B. braunii increased its lipid content from $46 \%$ to $54 \%$ under nitrogen starvation, D. salina decreased its lipid content from $25 \%$ to $9 \%$ and instead increased carbohydrates from $16 \%$ to $56 \%$ (Ben-Amote et al. 1985). It was also reported that the limitation of nitrogen could increase the oil content in all Chlorella strains (Illman et al. 2000). After extensive study, $\mathrm{Fe}_{3}{ }^{+}$concentration and its addition time was concluded to affect oil accumulation to some extent (Li et al. 2007; Liu et al. 2007). However, high light intensity, nutrient stress, and nitrogen deficiency are considered to be the key factors for satisfactory oil accumulation by microalgae (Solovchenko et al. 2009).

This of course, requires rigorous screening for identification and selection of strains producing and accumulating the desired end product. A phased approach was suggested, whereby, the algae are grown under non-limiting conditions in the first phase, followed by culture under nitrogenlimiting (not starvation) conditions in the second phase (Benemann and Oswald 1996). This imposes a growth rate limit on the algae and enables the algae to accumulate nutrients without the resultant decrease in biomass that nitrogen-deficient cultures face.

\subsection{Metabolic engineering}

Metabolomics aims to determine metabolic profiles to define the metabolome of a given lipid-rich algae. Metabo- 

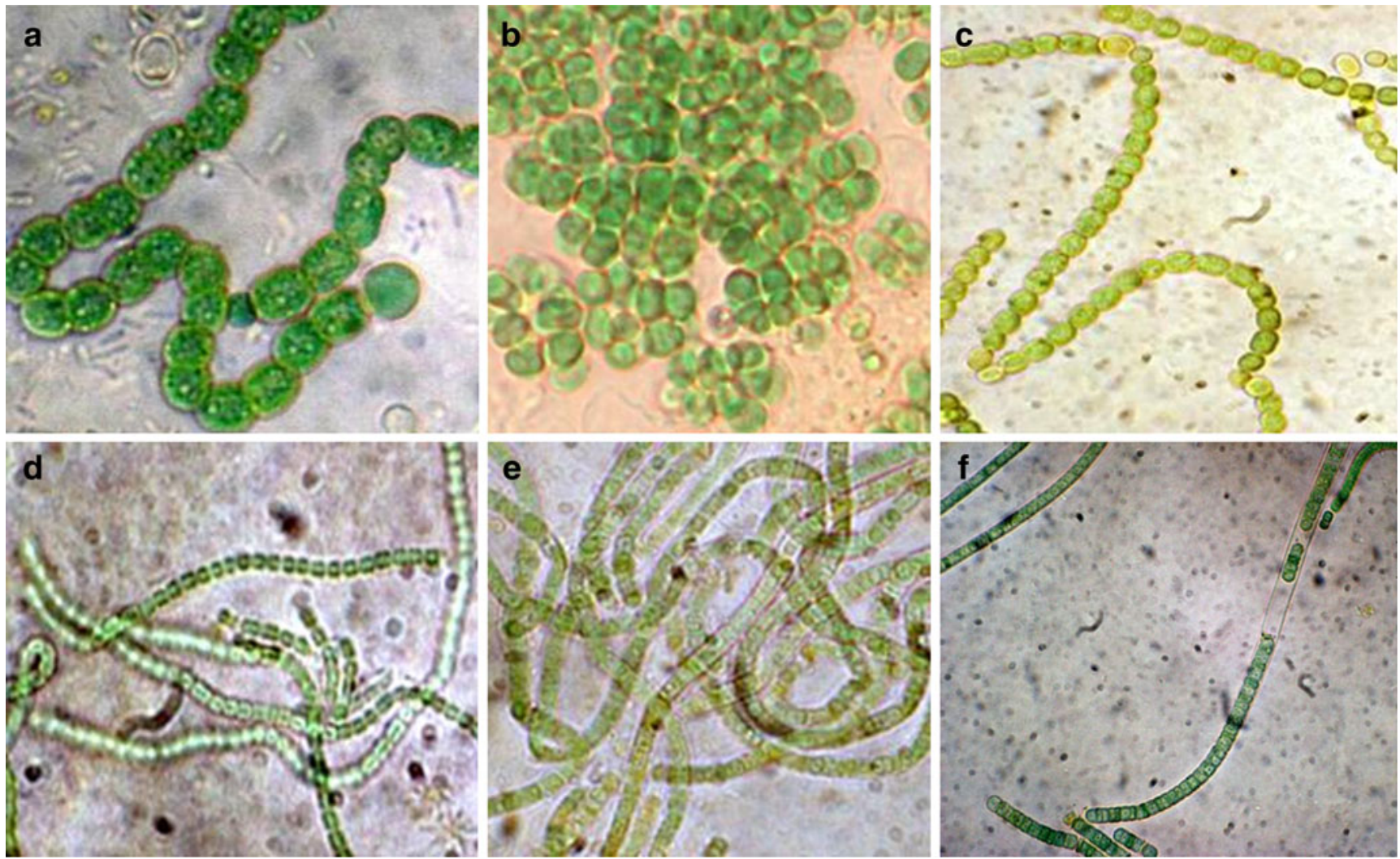

Fig. 4 Potential biohydrogen producing strains. a Anabaena, b Gloeocapsa, c Nostoc commune, d Microcystis, e Phormidium, f. Oscillatoria

nomics on the other hand helps in the statistical identification of differences in metabolite levels due to genetic or environmental changes and allows determination of accumulated metabolic intermediates and end products (Fiehn 2002; Nicholson et al. 2002; Lindon et al. 2004). To resolve the metabolic dynamics of microalgae, the metabolic flux can be studied by various techniques such as the monitoring of consumption and production of key compounds or the isotopic labeling of key metabolite precursors or intermediates and the monitoring of these isotopes in a timedependent manner (Yang et al. 2000; Fernie et al. 2005; Dong et al. 2006). Moreover, transcriptomics and proteomics offer possibility of identifying differentially expressed genes and proteins that are either directly involved in lipid biosynthesis and degradation or that are co-ordinately regulated (Anderson et al. 2004; McGrath et al. 2005; Dombrecht et al. 2007). The interpretation of these results alone is not straightforward as the accumulation can be due to an upregulated enzyme downstream or a downregulated enzyme upstream in the metabolic pathway. The identification of differentially expressed genes, proteins or metabolites gives clues to rate-limiting processes in the cell which can be backed up by the determination of metabolic flux. The system biology approach will allow fine-tuning of algal properties by genetic or metabolic engineering (Mus et al. 2007).

\subsubsection{Genetic engineering to improve algal productivity}

After identification of the pathways and key enzymes involved, genetic engineering has the potential to improve algal productivity. Routine transformation is currently carried out only for a few selected algal model species including Chlamydomonas reinhardtii, however, the growing field of transgenic microalgae has considerable potential (LeonBanares et al. 2004; Walker et al. 2005). Different transformation methods are available for the delivery of DNA into the algal genome with the "biolistic" technique being the most common one (Walker et al. 2005). This technique involves bombardment with DNA-coated microprojectiles and has been successfully used for a variety of algae including green algae and diatoms and is also the method of choice for chloroplast or mitochondrial genome transformation (Apt et al. 1996; Remacle et al. 2006; Kroth 2007). Other methods to create transgenic algae are the agitation of cells in the presence of glass beads and DNA, agitation with silicon-carbide whiskers and electroporation (Kindle 1990; Dunahay et al. 1997; Sun et al. 2005). More recent developments for the improved overexpression of transgenes involve the use of vectors containing nuclear matrix attachment regions to increase the expression level of foreign genes which has been carried out in the halotolerant alga D. salina (Wang et al. 2007). 
Table 4 Biohydrogen produced by selected cyanobacteria and their characteristics

\begin{tabular}{|c|c|c|c|}
\hline Organism description & Organisms name & $\begin{array}{l}\text { Maximum } \mathrm{H}_{2} \text { production } \\
(\mu \mathrm{mol} / \mathrm{mg} \mathrm{chl} \mathrm{a/h})\end{array}$ & References \\
\hline \multirow[t]{13}{*}{ Heterocystous filamentous cyanobacteria } & A. cylindrica & $0.91-2.1$ & Masukawa et al. 2001 \\
\hline & A. variabilis IAMM-58 & 4.2 & Masukawa et al. 2001 \\
\hline & A. variabilis & $0.05-167.6$ & $\begin{array}{l}\text { Fedorov et al. 2001; Happe et al. } \\
\text { 2000; Markov et al. } \\
\text { 1995; Moezelaar et al. 1996; } \\
\text { Sveshnikov et al. 1997; } \\
\text { Tsygankov et al. } 1998\end{array}$ \\
\hline & Anabaena flos-aquae UTEX 1444 & $1.7-3.2$ & Masukawa et al. 2001 \\
\hline & A. azollae & 38.5 & Sveshnikov et al. 1997 \\
\hline & A. cylindrica $\mathrm{B}-629$ & $0.103^{\mathrm{a}}$ & Lambert and Smith 1977 \\
\hline & Anabaenopsis circularis IAM M-13 & 0.31 & Masukawa et al. 2001 \\
\hline & Anabaena sp. PCC 7120 & 2.6 & Masukawa et al. 2001 \\
\hline & Calothrix scopulorum 1410/5 & $0.128^{\mathrm{a}}$ & Lambert and Smith 1977 \\
\hline & Calothrix membrnacea B-379 & $0.108^{\mathrm{a}}$ & Lambert and Smith 1977 \\
\hline & N. muscorum IAM M-14 & 0.60 & Masukawa et al. 2001 \\
\hline & Nostoc linckia IAM M-30 & 0.17 & Masukawa et al. 2001 \\
\hline & Nostoc commune IAM M-13 & 0.25 & Masukawa et al. 2001 \\
\hline \multirow[t]{3}{*}{ Non-heterocystous filamentous cyanobacteria } & Oscillatoria sp. Miami BG7 & $0.250^{\mathrm{a}}$ & Phlips and Mitsui 1983 \\
\hline & Oscillatoria limosa & 0.83 & Heyer et al. 1989 \\
\hline & Oscillatoria brevis B-1567 & $0.168^{\mathrm{a}}$ & Lambert and Smith 1977 \\
\hline \multirow[t]{9}{*}{ Non-heterocystous unicellular cyanobacteria } & Aphanocapsa montana & 0.40 & Howarth and Codd 1985 \\
\hline & Chroococcidiopsis thermalis & 0.7 & Serebryakova et al. 2000 \\
\hline & Gloebacter PCC 7421 & 1.38 & Moezelaar et al. 1996 \\
\hline & G. alpicola CALU 743 & $0.58^{\mathrm{c}}$ & Antal and Lindblad 2005 \\
\hline & Microcystis PCC 7820 & 0.16 & Moezelaar et al. 1996 \\
\hline & Mycrocystis PCC 7806 & $11.3^{\mathrm{b}}$ & Moezelaar and Stal 1994 \\
\hline & Synechococcus sp. & $0.02-0.66$ & Howarth and Codd 1985 \\
\hline & Synechocystis sp. & $0.07-0.13$ & Howarth and Codd 1985 \\
\hline & Cyanothece 7822 & 0.92 & Van der Oost et al. 1989 \\
\hline
\end{tabular}

\footnotetext{
${ }^{\mathrm{a}}$ Values expressed in $\mu \mathrm{mol} / \mathrm{mg}$ dry $\mathrm{wt} / \mathrm{h}$

${ }^{\mathrm{b}}$ Values expressed in $\mathrm{nmol} / \mathrm{mg}$ prot/h

${ }^{\mathrm{c}}$ Value expressed in $\mu \mathrm{mol} / \mathrm{mg}$ protein
}

\subsubsection{Biosynthesis of quality lipids}

The algal lipids biosynthesis requires acetyl-CoA as the starting point. Acetyl CoA carboxylase and other enzymes of the lipid biosynthesis pathway have been used as targets for improving oil production (Ratledge 2004; Richmond 2004). Lipid metabolism and the biosynthesis of fatty acids, glycerolipids, sterols, hydrocarbons, and ether lipids in eukaryotic algae have been studied in the context of optimization for biodiesel production (Metzger and Largeau 2005; Guschina and Harwood 2006). While C. reinhardtii serves as a model organism to study lipid biosynthesis in green algae, some unusual hydrocarbons and ether lipids (n-alkadienes, trienes, triterpenoid botryococcenes, methylated squalenes, and tetraterpenoids lycopadiene) from $B$. braunii have also been described (Achitouv et al. 2004; Metzger and Largeau 2005; Riekhof et al. 2005). Genetic engineering of key enzymes in specific fatty acid production pathways within lipid biosynthesis is a promising target for the improvement of both quantity and quality (chain length and saturation grade) of lipids.

\subsubsection{Increasing the proportion of monounsaturated lipids}

Microalgal lipids are predominantly polyunsaturated and therefore, are more prone to oxidation which is a serious issue with biodiesel while in storage. This drawback, however, can be corrected through partial catalytic hydrogenation of the oil (Chisti 2007). It is therefore, preferable that the level of polyunsaturated fatty acids in biodiesel is 
Table 5 Some high-value bio-products extracted from microalgae

\begin{tabular}{|c|c|c|c|}
\hline Product group & Applications & Examples/producer & References \\
\hline \multirow{5}{*}{$\begin{array}{l}\text { Phycobiliproteins } \\
\text { carotenoids }\end{array}$} & \multirow{5}{*}{$\begin{array}{l}\text { Pigments, cosmetics, pro } \\
\text { vitamins, pigmentation }\end{array}$} & Phycocyanin (Spirulina platensis) & Furuki et al. 2003; Spolaore et al. 2006 \\
\hline & & $\begin{array}{l}\text { Phycocyanin, phycoerythrin } \\
\text { (Porphyridium cruentum) }\end{array}$ & $\begin{array}{l}\text { Borowitzka 1997; Roman et al. 2002; } \\
\text { Servel et al. } 1994\end{array}$ \\
\hline & & $\begin{array}{l}\text { C-phycocyanin-hepatoprotective } \\
\text { effect (Spirulina platensis) }\end{array}$ & $\begin{array}{l}\text { Bhat and Madyastha 2000; } \\
\text { Vadiraja et al. } 1998\end{array}$ \\
\hline & & $\beta$-carotene $(D$. salina $)$ & $\begin{array}{l}\text { Borowitzka 1991; Ben-Amotz and Avron } \\
\text { 1990; Masjuk 1973; Olaizola } 2003\end{array}$ \\
\hline & & $\begin{array}{l}\text { Astaxanthin, leutin, zeaxantin } \\
\text { and canthaxantin } \\
\text { (Haematococcus pluvialis) }\end{array}$ & $\begin{array}{l}\text { Borowitzka 1997; Hirata et al. 2000; } \\
\text { Lorenz and Cysewski 2000; Olaizola } \\
\text { 2003; Piccardi et al. } 1999\end{array}$ \\
\hline \multirow[t]{3}{*}{$\begin{array}{l}\text { Polyunsaturated } \\
\text { fatty acids } \\
\text { (PUFAs) }\end{array}$} & \multirow[t]{3}{*}{$\begin{array}{r}\text { Food additive, } \\
\text { nutraceutical }\end{array}$} & $\begin{array}{l}\text { Eicosapentaenoic acid (EPA) (Chlorella } \\
\text { minutissima, Crypthecodinium) }\end{array}$ & $\begin{array}{l}\text { Apt and Behrens 1999; Belarbi et al. 2000; } \\
\text { Cardozo et al. 2007; Cohen 1999; } \\
\text { Radmer } 1996\end{array}$ \\
\hline & & $\begin{array}{l}\text { Docosahexaenoic acid (DHA) } \\
\text { (Schizochytrium sp, Gymnodinium, } \\
\text { Crypthecodinium, Ulkenia) }\end{array}$ & $\begin{array}{l}\text { Apt and Behrens 1999; Pulz and Gross } \\
\text { 2004; Radmer 1996; Valencia et al. } 2007\end{array}$ \\
\hline & & $\begin{array}{l}\text { Arachidonic acid (Parietochlorisincise, } \\
\text { Porphyridium cruentum) }\end{array}$ & Borowitzka 1997; Bigogno et al. 2002 \\
\hline \multirow[t]{3}{*}{ Vitamins } & \multirow[t]{3}{*}{ Nutrition } & Biotin (Euglena gracilis) & Baker et al. 1981 \\
\hline & & $\alpha$-tocopherol (Vitamin E) (Euglena gracilis) & Survase et al. 2006 \\
\hline & & $\begin{array}{l}\text { Ascorbic acid (Vitamin C) (P. moriformis, } \\
\text { Chlorella } \mathrm{spp})\end{array}$ & Bremus et al. 2006; Running et al. 2002 \\
\hline \multirow[t]{2}{*}{$\begin{array}{l}\text { Proteins/Amino } \\
\text { acids }\end{array}$} & Anti HIV-1 & $\begin{array}{l}\text { Cyanovirin-N (CV-N) } \\
\quad \text { (Nostoc ellipsosporum) }\end{array}$ & $\begin{array}{l}\text { Boyd 2001, 2002, 2004; Burja et al. 2001; } \\
\text { Yang et al. } 1999\end{array}$ \\
\hline & $\begin{array}{l}\text { Reversing activity against } \\
\text { multi drug resistance }\end{array}$ & Hapalosin (Hapalosiphon welwitschii) & Burja et al. 2001 \\
\hline \multirow[t]{5}{*}{ Alkaloids } & Immuno-suppressive & Microcolin (Lyngbya) & Koehn et al. 1992 \\
\hline & Hormothamnin & Harmathamnion enteromorphoides & Gerwick et al. 1992 \\
\hline & Antillatoxin- ichthiotoxic & Cyclodepsipeptides & Orjala et al. 1995 \\
\hline & $\begin{array}{l}\text { Acetogenin-cytotoxicity towards } \\
\text { leukaemic cells }\end{array}$ & Curacin- inhibits tubulin polymerization & Burja et al. 2002; Lai et al. 1996 \\
\hline & Anti-tuberculosis Activity & $\begin{array}{l}\text { (+)-8-hydroxymanzamine derivative, e.g., } \\
\text { Ircinol A, Manzamine A, Litosterol } \\
\text { (Litophyton viridis) }\end{array}$ & Donia and Hamann 2003 \\
\hline \multirow[t]{3}{*}{$\begin{array}{l}\text { Protease } \\
\text { Inhibitors }\end{array}$} & Elastase inhibiting activity & $\begin{array}{l}\text { Cyclic desipeptides (Scytonema hofmanni } \\
\text { pcc 7110) }\end{array}$ & Matern et al. 2001 \\
\hline & $\begin{array}{l}\text { Inhibitor of platelet activating } \\
\text { factor- induced platelet aggre- } \\
\text { gation }\end{array}$ & $\begin{array}{l}\text { Phosphoglyco-analog of acyl-acetylated } \\
\text { sphingosine, glyco-analog of phosphatidyl- } \\
\text { glycerol (Scytonema julianum) }\end{array}$ & Antonopoulou et al. 2005 \\
\hline & $\begin{array}{l}\text { Inhibitors of serine proteases, } \\
\text { including elastase }\end{array}$ & $\begin{array}{l}\text { Micropeptins, aerugenosins, microginins, } \\
\text { anabaenopeptins and microverdins }\end{array}$ & $\begin{array}{l}\text { Grach-Pogrebinsky et al. 2003; Matern et } \\
\text { al. 2001; Ploutno and Carmeli } 2005\end{array}$ \\
\hline \multirow{4}{*}{$\begin{array}{l}\text { Microalgal } \\
\text { Metabolites }\end{array}$} & Hypocholesterolemic effect & (Aphanizomenon flos-aquae) & Vlad et al. 1995 \\
\hline & Anticancer effect & $\begin{array}{c}\text { Diacylglycerols (Spirulina fusiformis, } \\
\text { Dunaliella and Phormidium tenue) }\end{array}$ & $\begin{array}{l}\text { Mathew et al. 1995; Schwartz and } \\
\text { Shklar 1987; Schwartz et al. 1988; } \\
\text { Tokuda et al. } 1996\end{array}$ \\
\hline & $\begin{array}{l}\text { Cytotoxicity against epidermoid } \\
\text { and adeno carcinoma cells }\end{array}$ & $\begin{array}{l}\text { Borophycin (Nostoc linckia and Nostoc } \\
\text { spongiaeforme var. tenue) }\end{array}$ & Burja et al. 2001 \\
\hline & Anti-inflammatory Activity & $\begin{array}{l}\text { Carotenoids ( } \beta \text {-carotene, lycopene, lutein; } \\
\text { C-phycocyanin }\end{array}$ & $\begin{array}{l}\text { Bhat and Madyastha 2000; Kerfeld 2004; } \\
\text { Vadiraja et al. } 1998\end{array}$ \\
\hline \multirow[t]{3}{*}{ Polysaccharides } & \multirow[t]{2}{*}{$\begin{array}{l}\text { food coating, emulsifying and } \\
\text { gelling agents, flocculants and } \\
\text { hydrating agents; remove toxic } \\
\text { metals }\end{array}$} & $\begin{array}{l}\text { Acidic sugars (glucuronic and/or galacturonic } \\
\text { acids) and other anionic organic (acetyl, } \\
\text { pyruvil) and inorganic (phosphate and } \\
\text { sulfate) substituent. }\end{array}$ & Otero and Vincenzini 2003 \\
\hline & & $\begin{array}{l}\text { Chrysolaminarin (a soluble } \beta \text {-1,3-polyglucan } \\
\text { (Phaeocystis pouchetii) }\end{array}$ & Borowitzka 1997; Laing and Ayala 1990 \\
\hline & $\begin{array}{l}\text { Inhibit tumor invasion and } \\
\text { metastasis }\end{array}$ & $\begin{array}{l}\text { Sulphated polysaccharide, calcium spirulans } \\
\text { (Aphanizomenon flos-aquae) }\end{array}$ & Mishima et al. 1998 \\
\hline
\end{tabular}


Table 5 (continued)

\begin{tabular}{|c|c|c|c|c|}
\hline Product group & Applications & Examples/producer & \multicolumn{2}{|l|}{ References } \\
\hline \multirow[t]{6}{*}{ Microbicides } & Bactericide & Spirogyra & \multicolumn{2}{|c|}{ Muller-Feuga et al. 2003} \\
\hline & Anti-viral & Anti-HIV & $\begin{array}{l}\text { Cyanoviridin-N } \\
\text { (Lyngbya } \\
\text { lagerheimeii and } \\
\text { Phormidium } \\
\text { tenue) }\end{array}$ & $\begin{array}{l}\text { Gustafson et al. } 1989 \text {; } \\
\text { Yang et al. } 1997\end{array}$ \\
\hline & & $\begin{array}{l}\text { Inhibits Herpes simplex, human } \\
\text { cytomegalovirus and measles virus }\end{array}$ & $\begin{array}{l}\text { Calcium spirulan } \\
\text { (Ca-SP) } \\
\text { (Lyngbya } \\
\text { lagerheimeii and } \\
\text { Phormidium } \\
\text { tenue) }\end{array}$ & $\begin{array}{l}\text { Ayehunie et al. 1998; } \\
\text { Hayashi and Hayashi } \\
\text { 1996; Hayashi et al. } \\
\text { 1996 }\end{array}$ \\
\hline & Anti-helminthic & $\begin{array}{l}\text { Dihydroxy tetrahydrofuran, Jasplakinolide } \\
\text { (brown algae-Notheia anomala) }\end{array}$ & \multicolumn{2}{|c|}{ Donia and Hamann 2003} \\
\hline & $\begin{array}{l}\text { Fungicide- apoptosis } \\
\text { of tumor cells }\end{array}$ & Cryptophycin (Nostoc sp. ATCC 53789) & \multicolumn{2}{|c|}{ Burja et al. 2001; Panda et al. 1998} \\
\hline & $\begin{array}{l}\text { Anti-protozoan: Leishmaniasis } \\
\text { treatment }\end{array}$ & $\begin{array}{l}\text { Sodium stibogluconate and meglumine } \\
\text { antimonite }\end{array}$ & \multicolumn{2}{|l|}{ Berman 1998} \\
\hline
\end{tabular}

kept to a minimum. In contrast, higher levels of polyunsaturated fats lower the cold filter plugging point; the temperature at which the fuel starts to form crystals/ solidifies and blocks the fuel filters of an engine. It can be seen that the extent of unsaturation in oil lowers its melting point. Therefore, colder climates require a higher unsaturated lipid content to enable the fuel to perform at low temperatures (Knothe 2005). Microalgae have excellent potential for the genetic modification of their lipid pathways either by upregulation of fatty acid biosynthesis or by downregulation of $\beta$-oxidation. By knocking out or modifying enzymes responsible for the synthesis of polyunsaturated lipids in the cell, it should be possible to dramatically increase the proportion of monounsaturated lipids.

\subsection{High-value coproduct strategy}

Microalgae are regarded as biorefinery for their capacity to produce a wide range of chemicals and biofuels from biomass by the integration of bioprocessing and appropriate low environmental impact chemical technologies in a cost effective and environmentally sustainable manner (Chisti 2007). They have excellent capacity of producing a large number of high-value bioactive compounds that can be used as pharmaceutical compounds, health foods, and natural pigments (Jiang 2000). Few well-studied examples include acetylic acids, $\beta$-carotene, vitamin $\mathrm{B}$, ketocarotenoid astaxanthin, polyunsaturated fatty acids, and lutein (Shi et al. 2002; Wen and Chen 2003; Jiang et al. 2004; He et al. 2005; Ip and Chen 2005; Huang et al. 2006; Del Campo et al. 2007; Table 5). The economical feasibility of microalgal biofuel production can be significantly enhanced by a high-value coproduct strategy, which would, concep- tually, involve sequentially the cultivation of microalgae in a microalgal farming facility ( $\mathrm{CO}_{2}$ mitigation), extracting bioreactive compounds from harvested algal biomass, thermal processing (pyrolysis, liquefaction, or gasification), extracting high-value chemicals from the resulting liquid, vapor, and/or solid phases, and reforming/upgrading biofuels for different applications (Chisti 2007).

\subsection{Cost-effective technologies for biomass harvesting and drying}

Limited light penetration and small size of microalgal cells (typically in the range of $2-20 \mu \mathrm{m}$ in diameter) leads to relatively low biomass concentration and thereby, enhances the costs and energy consumption for biomass harvesting. Diverse technologies including chemical flocculation, biological flocculation, filtration, centrifugation, and ultrasonic aggregation have been investigated for microalgal biomass harvesting (Divakaran and Pillai 2002; Bosma et al. 2003; Molina Grima et al. 2003; Olaizola 2003; Knuckey et al. 2006). In general, chemical and biological flocculation require low operating costs; however, they have the disadvantage of requiring long processing period and have the risk of bioreactive product decomposition. On the other hand, filtration, centrifuge and ultrasonic flocculation are more efficient but at the same time more costly. The selection of appropriate harvesting technology, therefore, depends on the value of the target products, biomass concentration, and the size of microalgal cells.

Biomass drying before lipid/bioproduct extraction and/or thermochemical processing is another step that needs to be taken into consideration. Sun drying is probably the cheapest drying method that has been employed for the processing of 
microalgal biomass (Millamena et al. 1990; Prakash et al. 1997). However, this method requires long drying period, large drying surface, and risks the loss of some bioreactive products. Low-pressure shelf drying is another low-cost drying technology that has been investigated which, nevertheless, is considered to be a low efficiency method (Prakash et al. 1997). More efficient but costly drying technologies investigated for drying microalgae include drum drying, spray drying, fluidized bed drying, freeze drying, and refractance window dehydration technology (Millamena et al. 1990; Prakash et al. 1997; Leach et al. 1998; Desmorieux and Decaen 2006; Nindo and Tang 2007). It is therefore, important to find a balance between harvesting and drying efficiency with the cost effectiveness to maximize the net energy output of the fuels from microalgae.

\subsection{Microalgal production with wastewater treatment}

Municipal and industrial wastewater treatments are the key infrastructural facilities that keep our cities, communities, and ecosystems sanitary. A great deal of money and effort is being spent on the removal of pollutants such as biochemical oxygen demand, turbidity, nitrogen, and phosphorus. Large confined animal feeding operations such as dairies can also be major sources of water pollution (Centner 2001). Nutrients like nitrogen and phosphorus can be removed from wastewaters in several ways. The most common method for removing nitrogen is denitrification which leads to reduction of nitrate to nitrogen gas (Metcalf and Eddy 2003). Phosphorus, on the other hand, is often removed by chemical precipitation using ferric chloride. However, both phosphorus and nitrogen can also be removed satisfactorily by growing bacteria or algae in the wastewater and then the biomass can be removed. The technique of promoting microalgal growth for nutrient removal was first developed by Oswald et al. (1957). Later, Singh and Dhar (2006, 2007) also worked on nitrogen and phosphorous removal from secondary treated sewage effluent with microalgae.

Using microalgae for wastewater treatment offers some interesting advantages over conventional methods. It has been shown to be a more cost-effective way to remove biochemical oxygen demand, pathogens, phosphorus, and nitrogen than activated sludge (Green et al. 1996; Singh and Dhar 2006). Traditional wastewater treatment processes involve the high energy costs of mechanical aeration to provide oxygen to aerobic bacteria to consume the organic compounds in the wastewater, whereas, microalgae provide an efficient way to consume nutrients and provide the aerobic bacteria with the needed oxygen through photosynthesis (Oswald et al. 1953). It is estimated that roughly $1 \mathrm{~kg}$ of biological oxygen demand removed in an activated sludge process requires $1 \mathrm{kWh}$ of electricity for aeration, which produces $1 \mathrm{~kg}$ of fossil $\mathrm{CO}_{2}$ from power generation. By contrast, $1 \mathrm{~kg}$ of biological oxygen demand removed by photosynthetic oxygenation requires no energy inputs and produces enough microalgal biomass to generate methane that can produce $1 \mathrm{kWh}$ of electric power (Oswald 2003).

\section{Conclusions}

Rapid industrial development, depletion of mineral oil reserves, and rise in atmospheric $\mathrm{CO}_{2}$ require the development of carbon-neutral renewable alternatives. Biofuel production from microalgae is supposed to provide technical and economic feasibility that has the potential for $\mathrm{CO}_{2}$ sequestration and is therefore, likely to get wide acceptance. Algal biofuels appear to be the only current renewable energy source that could meet the global demand for transport fuels (Schenk et al. 2008). For many centuries, various microalgal species have been exploited for the valuable protein source for animals. Currently, over 5,000 dry tons of microalgal biomass is produced annually in the world, mostly in "race way" or "high rate" type ponds for high-value nutritional supplements (Spolaore et al. 2006). The biggest challenge over the next few years in the microalgal biofuel field will be to reduce costs of cultivation and to further, improve the biology of biofuel production.

Economic feasibility of biofuels from microalgae can be enhanced by using efficient methods of biomass harvesting and drying, metabolic plus genetic engineering and system biology approaches, selection of efficient strains, high-value co-product strategy, and linking microalgal production with wastewater treatment. There is a need of more research on microalgal lipid structure and composition, quality of oil derived from waste-grown algae, fuel quality, suitability of algal oil for transportation, and its compatibility with newer technologies such as thermal depolymerization. Decision regarding location of biofuel production plant is crucial for land availability for large open ponds, requirement of appropriate climate (average temperature and solar insolation), communities and agro-industrial sites, need for wastewater treatment upgrades, proximities of algae production to biodiesel production sites and oil extraction plants, and ancillary industries for further processing of microalgal oil. Lastly, the bottlenecks in the complete cycle of microalgal biofuel production should be identified and overcome on pilot plants after optimization of growth conditions before the large-scale implementation potentials are realized.

Acknowledgments The authors gratefully acknowledge the assistance provided by the Department of Microbiology, C.P. College of Agriculture (SDAU, S. K. Nagar) and the Department of Microbiology, Indian Agricultural Research Institute, New Delhi for preparation of this manuscript. 


\section{References}

Achitouv E, Metzger P, Rager MN (2004) C31-C34 methylated squalene from a Bolivian strain of Botryococcus braunii. Phytochem 65:3159-3165

Acien Fernandez FG, Fernandez Sevilla JM, Sanchez Perez JA, Molina GE, Chisti Y (2001) Airlift-driven external-loop tubular photobioreactors for outdoor production of microalgae: assessment of design and performance. Chem Eng Sci 56(8):27212732

Akkerman I, Janssen M, Rocha J, Wijffels RH (2002) Photobiological hydrogen production: photochemical efficiency and bioreactor design. Int J Hydrogen Energy 27:1195-1208

Anderson RA (ed) (2005) Algal culturing techniques, Phycological Society of America. Elsevier Academic, USA, p 578

Anderson JP, Badruzsaufari E, Schenk PM, Manners JM, Desmond OJ, Ehlert C, Maclean DJ, Ebert PR, Kazan K (2004) Antagonistic interaction between abscisic acid and jasmonateethylene signalling pathways modulates defense gene expression and disease resistance. Plant Cell 16:3460-3479

Angelidaki I, Ahring BK (1993) Thermophilic anaerobic digestion of livestock waste: the effect of ammonia. Appl Microbiol Biotechnol 38:560-564

Antal TK, Lindblad P (2005) Production of $\mathrm{H}_{2}$ by sulphur-deprived cells of the unicellular cyanobacteria Gloeocapsa alpicola and Synechocystis sp. PCC 6803 during dark incubation with methane or at various extracellular $\mathrm{pH}$. J Appl Microbiol 98:114-120

Antonopoulou S, Karantonis HC, Nomikos T, Oikonomou A, Fragopoulou E, Pantazidou A (2005) Bioactive polar lipids from Chroococcidiopsis sp. (Cyanobacteria). Comp Biochem Physiol B Biochem Mol Biol 142:269-282

Aoyama K, Uemura I, Miyake J, Asada Y (1997) Fermentative metabolism to produce hydrogen gas and organic compounds in a cyanobacterium Spirulina platensis. J Ferment Bioeng 83:1720

Apt KA, Behrens PW (1999) Commercial developments in microalgal biotechnology. J Phycol 35:215-226

Apt KE, Kroth-Pancic PG, Grossman AR (1996) Stable nuclear transformation of the diatom Phaeodactylum tricornutum. Mol Gen Genet 252:572-579

Asinari Di San Marzano CM, Legros A, Naveau HP, Nyns EJ (1982) Biomethanation of the marine algae Tetraselmis. Int J Sustain Energy 1:263-272

Aslan S, Kapdan I (2006) Batch kinetics of nitrogen and phosphorus removal from synthetic wastewater by algae. Ecol Eng 28:64-70

Ayehunie S, Belay A, Baba TW, Ruprecht RM (1998) Inhibition of HIV-1 replication by an aqueous extract of Spirulina platensis. J Aquir Immun Defic Syndr Hum Retrovirol 18:7-12

Baker ER, McLaughlin JJA, Hutner SH (1981) Water-soluble vitamins in cells and spent culture supernatants of Poteriochromonas stipitata, Euglena gracilis and Tetrahymena thermophila. Arch Microbiol 129:310-313

Banerjee A, Sharma R, Chisti Y, Banerjee UC (2002) Botryococus braunii: a renewable source of hydrocarbons and other chemicals. Crit Rev Biotechnol 22:245-279

Barbosa B, Albrecht M, Wijffels R (2003) Hydrodynamic stress and lethal events in sparged microalgae cultures. Biotechnol Bioeng $83: 112-120$

Barclay WR, Terry KL, Nagle NJ, Weissman JC, Goebel RP (1985) Potential of new strains of marine and inland saline-adapted microalgae for aquaculture. J World Aquac Soc 18(40):218-228

Barclay WR, Meager KM, Abril JR (1994) Heterotrophic production of long chain omega-3 fatty acids utilizing algae and algae-like microorganisms. J Appl Phycol 6(2):123-129
Barnwal BK, Sharma MP (2005) Prospects of biodiesel production from vegetables oils in India. Renew Sustain Energy Rev 9:363378

Becker EW (1988) Micro-algae for human and animal consumption. In: Borowitzka MA, Borowitzka LJ (Eds.), Micro-algal technology, Cambridge University Press, pp. 222-256

Becker EW (2007) Micro-algae as a source of protein. Biotechnol Adv 25:207-210

Behrens PW, Kyle DJ (1996) Microalgae as a source of fatty acids. J Food Lipids 3:259-272

Belarbi EH, Molina Grima E, Chisti Y (2000) A process for high yield and scaleable recovery of high purity eicosapentaenoic acid esters from microalgae and fish oil. Enzyme Microb Technol 26 (7):516-529

Ben-Amote A, Tornabene TG, Thomas WH (1985) Chemical profile of selected species of microalgae with emphasis on lipids. J Phycol 21:72-81

Ben-Amotz A, Avron M (1990) The biotechnology of cultivating the halotolerant alga Dunaliella. Trends Biotechnol 8:121-126

Benemann JR (2007) "Biofuel, peak oil, and global warming 19772037" Presentation at California Polytechnic State University, San Luis Obispo, 1-18-07

Benemann JR (2008) Open ponds and closed photobioreactorscomparative economics. Paper presented at the 5th annual World Congress on Industrial Biotechnology and Bioprocessing, April 27-30, Chicago, IL, USA

Benemann JR, Oswald WJ (1996) Systems and economic analysis of microalgae ponds for conversion of carbon dioxide to biomass (Final Report: Grant No. DEFG22 93PC93204), Pittsburgh Energy Technology Centre, Pittsburgh, PA, US Department of Energy

Benemann J, Koopman B, Weismsman JC, Eisenberg DM, Oswald WJ (1977) Cultivation on sewage of microalgae harvestable by microstrainers (Contract Nos. W-74-05-ENG-48 and E-(04-3)34), Prepared for US Energy Research and Development Administration

Benemann JR, Goebel RP, Weissman JC, Augenstein DC (1982) Microalgae as a source of liquid fuels, (Final Technical Report, Contract Deacos 81 ER 30014), US Department of Energy

Berman J (1998) Chemotherapy of leishmaniasis: recent advances in the treatment of visceral disease. Curr Opin Infect Dis 11:707710

Berzin I (2005) Photobioreactor and process for biomass production and mitigation of pollutants in flue gases, United States Patent Application, Pub. no.: US2005/0260553 A1, USA, Publication date: Nov. 24, 2005

Bessou C Ferchaud F, Gabrielle B, Mary B (2010) Biofuels, greenhouse gases and climate change. A review. Agron Sustain Dev 1-79, (C) INRA, EDP Sciences. doi:10.1051/agro/2009039

Bhat VB, Madyastha KM (2000) C-phycocyanin: a potent peroxyl radical scavenger in vivo and in vitro. Biochem Biophys Res Commun 275:20-25

Bigogno C, Khozin-Goldberg I, Boussiba S, Vonshak A, Cohen Z (2002) Lipid and fatty acid composition of the green oleaginous alga Parietochloris incisa, the richest plant source of arachidonic acid. Phytochem 60:497-503

Blanchemain A, Grizeau D (1999) Increased production of eicosapentaenoic acid by Skeletonema costatum cells after decantation at low temperature. Biotechnol Tech 13(7):497-501

Borodyanski G, Konstantinov I (2003) Microalgae separator apparatus and method. US Patent No. US6524486B2, Sepal Technologies Ltd

Borowitzka LJ (1991) Development of Western Biotechnology's algal b-carotene plant. Bioresour Technol 38:251-252

Borowitzka MA (1992) Algal biotechnology products and processesmatching science and economics. J Appl Phycol 4(3):267-279 
Borowitzka MA (1997) Microalgae for aquaculture: opportunities and constraints. J Appl Phycol 9:393-401

Borowitzka MA (2005) Culturing microalgae in outdoor ponds. In: Andersen RA (ed) Algal culturing techniques. Elsevier Academic, New York, pp 205-218

Bosma R, van Spronsen W, Tramper J, Wijffels R (2003) Ultrasound, a new separation technique to harvest microalgae. J Appl Phycol $15: 143-153$

Boyd MR (2001) Anti-cyanovirin antibody with an internal image of gp120, a method of use thereof, and a method of using a cyanovirin to induce an immune response to gp120, United States patent no 6193982

Boyd MR (2002) Methods of using cyanovirins topically to inhibit viral infection, United States patent no 6420336

Boyd MR (2004) Methods of using cyanovirins to inhibit viral infection, United States patent no 6743577

Bremus C, Herrmann U, Bringer-Meyer S, Sahm H (2006) The use of microorganisms in L-ascorbic acid production. J Biotechnol 124:196-205

Bridgwater A, Maniatis K (2004) The production of biofuels by thermal chemical processing of biomass. In: Archer M, Barber J (eds) Molecular to global photosynthesis. Imperial College Press, London, pp 521-611

Brzezinski MA (1985) The Si-C-N ratio of marine diatoms: interspecific variability and the effect of some environmental variables. J Phycol 21:347-357

Burja AM, Banaigs B, Abou-Mansour E, Burgess JG, Wright PC (2001) Marine cyanobacteria - a prolific source of natural products. Tetrahedron 57:9347-9377

Burja AM, Abou-Mansour BEB, Payri C, Burgess JG, Wright PC (2002) Culture of marine cyanobacterium, Lyngbya majuscule (Oscillatoriaceae), for bioprocess intensified production of cyclic and linear lipopeptides. J Microbiol Meth 48:207-219

Cardozo KHM, Guaratini T, Barros MP, Falcao VR, Tonon AP, Lopes NP, Campos S, Torres MA, Souza AO, Colepicolo P, Pinto E (2007) Metabolites from algae with economical impact. Compe Biochem Physiol C Toxicol Pharmacol 146:60-78

Carvalho AP, Meireles LA, Malcata FX (2006) Microalgal reactors: a review of enclosed system designs and performances. Biotechnol Prog 22:1490-1506. doi:10.1021/bp060065r

Centner TJ (2001) Evolving policies to regulate pollution from animal feeding operations. Environ Manag 28:599-609

Ceron Garcia MC, Fernandez Sevilla JM, Acien Fernandez FG, Molina Grima E, Garcia Camacho F, Ceron Garcia MC, Fernandez Sevilla JM, Acien Fernandez FG, Molina Grima E, Garcia Camacho F (2000) Mixotrophic growth of Phaeodactylum tricornutum on glycerol: growth rate and fatty acid profile. J Appl Phycol 12(3):239-248

Chae SR, Hwang EJ, Shin HS (2006) Single cell protein production of Euglena gracilis and carbon dioxide fixation in an innovative photo-bioreactor. Bioresour Technol 97(2):322-329

Chen PH (1987) Factors influencing methane fermentation of microalgae. $\mathrm{PhD}$ thesis, University of California, Berkeley, CA, USA

Chen GQ, Chen F (2006) Growing phototrophic cells without light. Biotechnol Lett 28(9):607-616

Chen Y, Cheng JJ, Creamer KS (2008a) Inhibition of anaerobic digestion process: a review. Bioresour Technol 99:40444064

Chen GQ, Jiang Y, Chen F (2008b) Variation of lipid class composition in Nitzschia laevis as a response to growth temperature change. Food Chem 109:88-94

Chisti Y (2007) Biodiesel from microalgae. Biotechnol Adv 25 (3):294-306. doi:10.1016/j.biotechadv.2007.02.001

Christie WW (2003) Lipid analysis. The Oily Press, PJ Barnes and Associates: Bridgewater, NJ
Cirne DG, Paloumet X, Bjornsson L, Alves MM, Mattiasson B (2007) Anaerobic digestion of lipid-rich waste - effects of lipid concentration. Renew Energy 32:965-975

Clark GJ, Langley D, Bushell ME (1995) Oxygen limitation can induce microbial secondary metabolite formation: investigations with miniature electrodes in shaker and bioreactor culture. Microbiol 141:663-669

Cohen Z (1999) Porphyridium cruentum. In: Cohen Z (ed) Chemicals from microalgae. CRC Press, Taylor and Francis, New York, pp $1-24$

Del Campo JA, Garcia-Gonzalez M, Guerrero MG (2007) Outdoor cultivation of microalgae for carotenoid production: current state and perspectives. Appl Microbiol Biotechnol 74:1163-1174. doi:10.1007/s00253-007-0844-9

Demirbas A (2005) Biodiesel production from vegetable oils via catalytic and non-catalytic supercritical methanol transesterification methods. Prog Energ Combust Sci 31(5-6):466-487

Desmorieux H, Decaen N (2006) Convective drying of Spirulina in thin layer. J Food Eng 77:64-70

Dijkstra AJ (2006) Revisiting the formation of trans-isomers during partial hydrogenation of triacylglycerol oils. Eur J Lipid Sci Technol 108(3):249-264

Dismukes GC, Damian C, Nicholas B, Gennady MA, Matthew CP (2008) Aquatic phototrophs: efficient alternatives to land-based crops for biofuels. Curr Opin Biotechnol 19:235-240

Divakaran R, Pillai VNS (2002) Flocculation of algae using chitosan. J Appl Phycol 14:419-422

Dombrecht B, Xue GP, Sprague SJ, Kirkegaard JA, Ross JJ, Reid JB, Fitt GP, Sewelam N, Schenk PM, Manners JM, Kazan K (2007) AtMYC2 modulates diverse jasmonate-dependent functions by coordination of a transcriptional cascade. Plant Cell 19:22252245

Dong QL, Zhao XM, Ma HW, Xing XY, Sun NX (2006) Metabolic flux analysis of the two astaxanthin-producing microorganisms Haematococcus pluvialis and Phaffia rhodozyma in the pure and mixed cultures. Biotechnol J 1:1283-1292

Donia M, Hamann MT (2003) Marine natural products and their potential application as anti-infective agents. Lancet 3:338348

Doucha J, Livansky K (2006) Productivity, $\mathrm{CO}_{2} / \mathrm{O}_{2}$ exchange and hydraulics in outdoor open high density microalgal (Chlorella sp.) photobioreactors operated in a middle and southern European climate. J Appl Phycol 18:811-826

Doucha J, Straka F, Livansky K (2005) Utilization of flue gas for cultivation of microalgae (Chlorella sp.) in an outdoor open thinlayer photobioreactor. J Appl Phycol 17:403-412. doi:10.1007/ s10811-005-8701-7

Duerr EO, Molnar A, Sato V (1998) Cultured microalgae as aquaculture feeds. J Mar Biotechnol 6(2):65-70

Dunahay TG, Adler SA, Jarvik JW (1997) Transformation of microalgae using silicon carbide whiskers. Meth Mol Biol 62:503-509

Metcalf and Eddy (2003) Wastewater Engineering: Treatment, Disposal, Reuse. McGraw Hill Publishing, New York

Ekman A, Bulow L, Stymne S (2007) Elevated atmospheric $\mathrm{CO}_{2}$ concentration and diurnal cycle induce changes in lipid composition in Arabidopsis thaliana. New Phytol 174:591-599. doi:10.1111/j.1469-8137.2007.02027.x

Fang X, Wei C, Zhao-Ling C, Fan O (2004) Effects of organic carbon sources on cell growth and eicosapentaenoic acid content of Nannochloropsis sp. J Appl Phycol 16:499-503

Fedorov AS, Tsygankov AA, Rao KK, Hall DO (2001) Production of hydrogen by an Anabaena variabilis mutant in photobioreactor under aerobic outdoor conditions. In: Miyake J, Matsunaga T, San Pietro A (eds) BioHydrogen II. Elsevier, New York, pp 223228 
Feinberg DA (1984) Fuel options from microalgae with representative chemical compositions (SERI/TP-231-2427), Solar Energy Research Institute, Golden, CO, July 2004

Felizardo P, Correia MJN, Raposo I, Mendes JF, Berkemeier R, Bordado JM (2006) Production of biodiesel from waste frying oil. Waste Manage 26(5):487-494

Fernie AR, Geigenberger P, Stitt M (2005) Flux an important, but neglected, component of functional genomics. Curr Opin Plant Biol 8:174-182

Fiehn O (2002) Metabolomics-the link between genotypes and phenotypes. Plant Mol Biol 48:155-171

Fukuda H, Kondo A, Noda H (2001) Biodiesel fuel production by transesterification of oils. J Biosci Bioeng 92(5):405-416

Furuki T, Maeda S, Imajo S, Hiroi T, Amaya T, Hirokawa T, Ito K, Nozawa H (2003) Rapid and selective extraction of phycocyanin from Spirulina platensis with ultrasonic cell disruption. J Appl Phycol 15:319-324

Galinski E (1995) Osmoadaptation in bacteria. Adv Microb Physiol 37:273-328

Gavrilescu M, Chisti Y (2005) Biotechnology—a sustainable alternative for chemical industry. Biotechnol Adv 23:471-499

Gerwick WH, Jiang ZD, Agarwal SK, Farmer BT (1992) Total structure of hormothamnin-A, A toxic cyclic undecapeptide from the tropical marine cyanobacterium hormothamnion enteromorphoides. Tetrahedron 48:2313-2324

Goldman JC (1979) Outdoor mass algal cultures-II, photosynthetic yield limitations. Water Res 11:119-136

Golueke CG, Oswald WJ (1959) Biological conversion of light energy to the chemical energy of methane. Appl Microbiol 7:219-227

Golueke CG, Oswald WJ (1965) Harvesting and processing sewagegrown planktonic algae. J Water Poll Cont Fed 37:471-498

Golueke CG, Oswald WJ, Gottas HB (1957) Anaerobic digestion of algae. Appl Microbiol 5:47-55

Grach-Pogrebinsky O, Sedmak B, Carmeli S (2003) Protease inhibitors from a Slovenian Lake Bled toxic waterbloom of the cyanobacterium Planktothrix rubescens. Tetrahedron 59:83298336

Green FB, Bernstone LS, Lundquist TJ, Oswald WJ (1996) Advanced integrated wastewater pond systems for nitrogen removal. Water Sci Technol 33(7):207-217

Grobbelaar JU (1994) Turbulence in mass algal cultures and the role of light/dark fluctuations. J Appl Phycol 6(3):331-335

Gudin C, Therpenier C (1986) Bioconversion of solar energy into organic chemicals by microalgae. Adv Biotechnol Process 6:73110

Guerin M, Huntley ME, Olaizola M (2003) Haematococcus astajanthin: applications for human health and nutrition. Trends Biotechnol 21:210-216

Guschina IA, Harwood JL (2006) Lipids and lipid metabolism in eukaryotic algae. Prog Lipid Res 45:160-186

Gustafson KR, Cardellina IIJH, Fuller RW, Weislow OS, Kiser RF, Snader KM, Patterson GML, Boyd MR (1989) AIDS-antiviral sulfolipids from cyanobacteria (blue-green algae). J Nat Can Inst $81: 1254-1258$

Han X, Miao XL, Wu QY (2006) High quality biodiesel production from heterotrophic growth of Chlorella protothecoides in fermenters by using starch hydrolysate as organic carbon. J Biotechnol 126(4):499-507

Hankamer B, Lehr F, Rupprecht J, Mussgnug JH, Posten C, Kruse O (2007) Photosynthetic biomass and $\mathrm{H}_{2}$ production: from bioengineering to bioreactor scale up. Physiol Plant 131:10-21. doi:10.1111/j.1399-3054.2007.00924.x

Happe T, Schutz K, Bohme H (2000) Transcriptional and mutational analysis of the uptake hydrogenase of the filamentous cyanobacterium Anabaena variabilis ATCC 29413. J Bacteriol 182:16241631
Harrison PJ, Berges JA (2005) Marine culture media. In: Andersen RA (ed) Algal culturing techniques. Phycological Society of America, Elsevier, Academic Press, Amsterdam, pp 21-34

Hayashi T, Hayashi K (1996) Calcium spirulan, an inhibitor of enveloped virus replication, from a blue- green alga Spirulina platensis. J Nat Prod 59:83-87

Hayashi K, Hayashi T, Kojima I (1996) A natural sulfated polysaccharide, calcium spirulan, isolated from Spirulina platensis: in vitro and ex vivo evaluation of anti-herpes simplex virus and anti-human immunodeficiency virus activities. AIDS Res Hum Retrovir 12:1463-1471

He HZ, Li HB, Chen F (2005) Determination of vitamin B1 in seawater and microalgal fermentation media by highperformance liquid chromatography with fluorescence detection. Anal Bioanal Chem 383:875-879

Heasman M, Diemar J, O'connor W, Sushames T, Foulkes L (2000) Development of extended shelf-life microalgae concentrate diets harvested by centrifugation for bivalve molluscs - a summary. Aquac Res 31(8-9):637-659

Heyer H, Stal LJ, Krumbein WE (1989) Simultaneous heterolatic and acetate fermentation in the marine cyanobacterium Oscillatoria limosa incubated anaerobically in the dark. Arch Microbiol 151:558-564

Hirano A, Ryohei U, Shin H, Ogushi Y (1997) $\mathrm{CO}_{2}$ fixation and ethanol production with microalgal photosynthesis and intracellular anaerobic fermentation. Energy 22:137-142

Hirata T, Tanaka M, Ooike M, Tsunomura T, Sakaguchi M (2000) Antioxidant activities of phycocyanobilin prepared from $S$. platensis. J Appl Phycol 12:435-439

Howarth DC, Codd GA (1985) The uptake and production of molecular hydrogen by unicellular cyanobacteria. J Gen Microbiol 131:1561-1569

$\mathrm{Hu}$ Q, Sommerfeld M, Jarvis E, Ghirardi M, Posewite M, Seibert M, Darzins A (2008) Microalgal triacylglycerols as feedstocks for biofuel production: perspectives and advances. Plant J 54:621639. doi:10.1111/j.1365-313X.2008.03492.x

Huang JC, Chen F, Sandmann G (2006) Stress-related differential expression of multiple b-carotene ketolase genes in the unicellular green alga Haematococcus pluvialis. J Biotechnol 122:176185

Huntley ME, Redalje DG (2007) $\mathrm{CO}_{2}$ Mitigation and renewable oil from photosynthetic microbes: a new appraisal. Mitig Adapt Strateg Glob Change 12:573-608. doi:10.1007/s11027-0067304-1

Illman AM, Scragg AH, Shales SW (2000) Increase in Chlorella strains calorific values when grown in low nitrogen medium. Enzym Microb Technol 27:631-635

Ip PF, Chen F (2005) Employment of reactive oxygen species to enhance astaxanthin formation in Chlorella zofingiensis in heterotrophic culture. Process Biochem 40:3491-3496

Jeffries TW, Timourien H, Ward RL (1978) Hydrogen production by Anabaena cylindrica: effect of varying ammonium and ferric ions, $\mathrm{pH}$ and light. Appl Environ Microbiol 35:704-710

Jiang FC (2000) Algae and their biotechnological potential. Kluwer Academic Publishers, Dordrecht

Jiang Y, Fan KW, Wong RTY, Chen F (2004) Fatty acid composition and squalene content of the marine microalga Schizochytrium mangrovei. J Agric Food Chem 52:1196-1200

Kapdan IK, Kargi F (2006) Bio-hydrogen production from waste materials. Enzyme Microb Technol 38:569-582

Kerfeld CA (2004) Structure and function of the water-soluble carotenoid-binding proteins of cyanobacteria. Photosynth Res $81: 215-225$

Khan Z, Bhadouria P, Bisen PS (2005) Nutritional and therapeutic potential of Spirulina. Curr Pharma Biotechnol 6(5):373379 
Khozin-Goldberg I, Cohen Z, Pimenta-Leibowitz M, Nechev J, Zilberg D (2006) Feeding with arachidonic acid-rich triacylglycerols from the microalga Parietochoris incisa increased recovery of guppies from infection with Tetrahymena sp. Aquaculture 255:142-150

Kim DD (1990) Outdoor mass culture of Spirulina platensis in Vietnam. J Appl Phycol 2(2):179-181

Kindle KL (1990) High-frequency nuclear transformation of Chlamydomonas reinhardtii. Proc Natl Acad Sci USA 87:1228-1232

Kirst G (1990) Salinity tolerance of eukaryotic marine-algae. Ann Rev Plant Physiol Plant Mol Biol 41:21-53

Knothe GH (2005) Dependence of biodiesel fuel properties on the structure of fatty acid alkyl esters. Fuel Process Technol 86 (10):1059-1070. doi:10.1016/j.fuproc.2004.11.002

Knuckey RM, Brown MR, Robert R, Frampton DMF (2006) Production of microalgal concentrates by flocculation and their assessment as aquaculture feeds. Aquacult Eng 35:300-313. doi:10.1016/j.aquaeng.2006.04.001

Koehn FE, Longley RE, Reede T (1992) Microcolins A and B, new immunosuppressive peptides from the blue-green alga Lyngbya majuscule. J Nat Prod 55:613-619

Kristensen E (1990) Characterization of biogenic organic matter by stepwise thermogravimetry (STG). Biogeochem 9:135-159

Kroth PG (2007) Genetic transformation: a tool to study protein targeting in diatoms. Meth Mol Biol 390:257-268

Kruse O, Rupprecht J, Mussgnug JR, Dismukes GC, Hankamer B (2005) Photosynthesis: a blueprint for solar energy capture and biohydrogen production technologies. Photochem Photobiol Sci 4:957-970

Kugelman IJ, McCarty PL (1965) Cation toxicity and stimulation in anaerobic waste treatment. I. Slug feed studies. J Water Pollut Control Fed 37:97-116

Kulkarni MG, Dalai AK (2006) Waste cooking oils an economical source for biodiesel, a review. Ind Eng Chem Res 45:2901-2913

Kurat CF, Natter K, Petschnigg J, Wolinski H, Scheuringer K, Scholz H, Zimmermann R, Leber R, Zechner R, Kohlwein SD (2006) Obese yeast: triglyceride lipolysis is functionally conserved from mammals to yeast. J Biol Chem 281:491-500. doi:10.1074/jbc. M508414200

Lai JY, Yu J, Mekonnen B, Falck JR (1996) Synthesis of curacin A, an antimitotic cyclopropane-thiazoline from the marine cyanobacterium Lyngbya majuscule. Tetrahedron Lett 37:7167-7170

Laing I, Ayala F (1990) Commercial mass culture techniques for producing microalgae. In: Akatsuka I (ed) Introduction to applied phycology. SPB, The Hague, pp 447-477

Lambert GR, Smith GD (1977) Hydrogen formation by marine bluegreen algae. FEBS Lett 83:159-162

Leach G, Oliveira G, Morais R (1998) Spray-drying of Dunaliella salina to produce a b-carotene rich powder. $\mathrm{J}$ Ind Microbiol Biotech 20:82-85

Lee YK (1997) Commercial production of microalgae in the Asia Pacific rim. J Appl Phycol 9(5):403-411

Lee CG (1999) Calculation of light penetration depth in photobioreactors. Biotechnol Bioprocess Eng 4:78-81

Lee YK (2001) Microalgal mass culture systems and methods: their limitation and potential. J Appl Phycol 13:307-315

Lee YK, Low CS (1992) Productivity of outdoor algal cultures in enclosed tubular photobioreactor. Biotechnol Bioeng 40:11191122

Lee SJ, Jim SB, Jim JE, Kwon GS, Woon BD, Oh HM (1998) Effects of harvesting method and growth stage on the flocculation of the green alga Botryococcus braunii. Lett Appl Microbiol 27(1):1418

Leon-Banares R, Gonzalez-Ballester D, Galvan A, Fernandez E (2004) Transgenic microalgae as green cell-factories. Trends Biotechnol 22:45-52. doi:10.1016/j.tibtech.2003.11.003
Levin GV, Clendenning JR, Gibor A, Bogar FD (1961) Harvesting of algae by froth flotation. Appl Environ Microbiol 10(2):169-175

Li YY, Sasaki H, Yamashita K, Seki K, Kamigochi I (2002) High-rate methane fermentation of lipid-rich food wastes by a high-solids co-digestion process. Water Sci Technol 45(12):143-150

Li X, Xu H, Wu Q (2007) Large-scale biodiesel production from microalga Chlorella protothecoides through heterotrophic cultivation in bioreactors. Biotechnol Bioeng 98(4):764-771

Liang XA, Dong WB, Miao XJ, Dai CJ (2006) Production technology and influencing factors of microorganism grease. Food Res Dev 27(3):46-47

Lindon JC, Holmes E, Nicholson JK (2004) Metabonomics and its role in drug development and disease diagnosis. Expert Rev Mol Diagn 4:189-199

Liu ZY, Wang GC, Zhou BC (2007) Effect of iron on growth and lipid accumulation in Chlorella vulgaris. Bioresour Technol 99:47174722

Lorenz RT, Cysewski GR (2000) Commercial potential for Haematococcus microalgae as a natural source of astaxanthin. Trends Biotechnol 18:160-167

Lu C, Vonshak A (1999) Photoinhibition in outdoor Spirulina platensis cultures assessed by polyphasic chlorophyll fluorescence transients. J Appl Phycol 11:355-359

Margheri MC, Tredici MR, Allotta G, Vagnoli L (1990) Heterotrophic metabolism and regulation of uptake hydrogenase activity in symbiotic cyanobacteria. In: Polsinelli M, Materassi R, Vincenzini M (eds) Developments in plant and soil sciencesbiological nitrogen fixation. Kluwer Academic Publishers, Dordrecht, pp 481-486

Markov SA, Bazin MJ, Hall DO (1995) Hydrogen photoproduction and carbon dioxide uptake by immobilized Anabaena variabilis in a hollow-fibre photobioreactor. Enzyme Microbial Technol 17:306-310

Masjuk NP (1973) Morphology, taxonomy, ecology, geographical distribution and utilization of Dunaliella (in Russian). Naukowa, Kiev, $244 \mathrm{p}$

Masukawa H, Nakamura K, Mochimaru M, Sakurai H (2001) Photobiological hydrogen production and nitrogenase activity in some heterocystous cyanobacteria. In: Miyake J, Matsunaga T, San Pietro A (Eds.), BioHydrogen II, Elsevier, pp. 63-66.

Matern U, Oberer L, Falchetto RA, Erhard M, Konig WA, Herdman M, Weckesser J (2001) Scyptolin A and B, cyclic depsipeptides from axenic cultures of Scytonema hofmanni PCC 7110. Phytochem 58:1087-1095

Mathew B, Sankaranarayanan R, Padmanabhan P (1995) Evaluation of chemoprevention of oral cancer with Spirulina fusiformis. Nutr Cancer 24(2):197-202

Mc Carty PL (1964) Anaerobic waste treatment fundamentals. Public Works 95(9):91-99

McGrath KC, Dombrecht B, Manners JM, Schenk PM, Edgar CI, Maclean DJ, Scheible WR, Udvardi MK, Kazan K (2005) Repressor and activator-type ethylene response factors functioning in jasmonate signalling and disease resistance identified via a genome wide screen of Arabidopsis transcription factor gene expression. Plant Physiol 139:949-959

Meher LC, Vidya SD, Naik SN (2006) Technical aspects of biodiesel production by transesterification, a review. Renew Sustain Energy Rev 10:248-268

Metting F (1996) Biodiversity and application of microalgae. J Ind Microbiol Biotech 17:477-489

Metzger P, Largeau C (2005) Botryococcus braunii: a rich source for hydrocarbons and related ether lipids. Appl Microbiol Biotechnol 66:486-496

Miao XL, Wu QY (2004) High yield bio-oil production from fast pyrolysis by metabolic controlling of Chlorella protothecoides. $\mathrm{J}$ Biotechnol 110:85-93 
Miao XL, Wu QY (2006) Biodiesel production from heterotrophic microalgal oil. Bioresour Technol 97:841-846. doi:10.1016/j. biortech.2005.04.008

Millamena OM, Aujero EJ, Borlongan IG (1990) Techniques on algae harvesting and preservation for use in culture and as larval food. Aquac Eng 9:295-304

Mishima T, Murata J, Toyoshima M, Fujii H, Nakajima M, Hayashi T, Kato T, Saiki I (1998) Inhibition of tumor invasion and metastasis by calcium spirulan (Ca-SP), a novel sulfated polysaccharide derived from a blue-green alga, Spirulina platensis. Clin Exp Metastasis 16:541-550

Moezelaar R, Stal LJ (1994) Fermentation in the unicellular cyanobacterium Microcystis PCC7806. Arch Microbiol 162:63-69

Moezelaar R, Bijvank SM, Stal LJ (1996) Fermentation and sulfur reduction in the mat-building cyanobacterium Microcoleus chtonoplastes. Appl Environ Microbiol 62:1752-1758

Molina Grima E, Camacho FG, Fernandez FGA (1999) Production of EPA from Phaeodactylum tricornutum. In: Cohen Z (ed) Chemicals from microalgae. CRC Press, Taylor and Francis, New York, pp 57-92

Molina Grima E, Belarbi EH, Fernandez FGA, Robles M, Chisti Y (2003) Recovery of microalgal biomass and metabolites: process options and economics. Biotechnol Adv 20:491-515. doi:10.1016/S0734-9750(02)00050-2

Molina GE, Fernandez FGA, Chisti Y (2001) Tubular photobioreactor design for algal cultures. J Biotechnol 92(2):113-131

Moore J (2009) Microalgae from biodiesel to bioethanol and beyond www.http://snrecmitigation.wordpress.com/2009/03/23/

Moo-Young M, Blanch HW (1987) Transport phenomena and bioreactor design. In: Bu'Lock J, Kristiansen B (eds) Basic biotechnology. Academic, New York, pp 133-172

Muller-Feuga A, Moal J, Kaas R (2003) The microalgae for aquaculture. In: Stottrup JG, McEvoy LA (eds) Life feeds in marine aquaculture. Blackwell, Oxford, pp 206-252

Mus F, Dubini A, Seibert M, Posewitz MC, Grossman AR (2007) Anaerobic acclimation in Chlamydomonas reinhardtii: anoxic gene expression, hydrogenase induction, and metabolic pathways. J Biol Chem 282:25475-25486. doi:10.1074/jbc. M701415200

Mussgnug J, Thomas-Hall S, Rupprecht J, Foo A, Klassen V, McDowall A, Schenk PM, Kruse O, Hankamer B (2007) Engineering photosynthetic light capture: Impacts on improved solar energy to biomass conversion. Plant Biotech J 5:802-814. doi:10.1111/j.1467-7652.2007.00285.x

Nagle N, Lemke P (1989) Microalgal fuel production processes: analysis of lipid extraction and conversion methods, paper presented at the aquatic species program, Solar Energy Research Institute, Golden, CO. May 3-4, 1989

Nagle N, Lemke P (1990) Production of methyl-ester fuel from microalgae. Appl Biochem Biotechnol 24(5):355-361

Nakamura T, Senior CL, Olaizola M, Bridges T, Flores S, Sombardier L, Masutani SM (2005) Recovery and sequestration of $\mathrm{CO}_{2}$ from stationary combustion systems by photosynthesis of microalgae (Final Report, Contract No. DE-FC26-00NT 40934), US Department of Energy, pp. 220

Nicholson JK, Connelly J, Lindon JC, Holmes E (2002) Metabonomics: a platform for studying drug toxicity and gene function. Nat Rev Drug Discovery 1:153-161

Nindo CI, Tang J (2007) Refractance window dehydration technology: a novel contact drying method. Drying Technol 25:37-48

Olaizola M (2000) Commercial production of astaxanthin from Haematococcus pluvialis using 25,000-liter outdoor photobioreactors. J Appl Phycol 12(3):499-506

Olaizola M (2003) Commercial development of microalgal biotechnology: from the test tube to the marketplace. Biomol Eng 20:459-466
Olguin EJ (2000) The cleaner production strategy applied to animal production. In: Olguin EJ, Sanchez G, Hernandez E (eds) Environmental biotechnology a cleaner bioprocesses. Taylor and Francis, London, pp 227-243

Omil F, Mendez R, Lema JM (1995) Anaerobic treatment of saline wastewaters under high sulfide and ammonia content. Bioresour Technol 54:269-278

Opute FL (1974) Lipid and fatty acid composition of diatoms. J Exp Bot 25(87):823-835

Orjala J, Nagle DG, Hsu VL, Gerwick WH (1995) Antillatoxin: an exceptionally ichthyotoxic cyclic lipopeptide from the tropical cyanobacterium Lyngbya majuscule. J Am Chem Soc 117:82818282

Oswald WJ (1962) The coming industry of controlled photosynthesis. Am J Public Health 52:2

Oswald WJ (2003) My sixty years in applied algology. J Appl Phycol 15:99-106

Oswald WJ, Gotaas HB, Ludwig HF, Lynch V (1953) Algae symbiosis in oxidation ponds: photosynthetic oxygenation. Sew Ind Wastes 25(6):692-705

Oswald WJ, Gotaas HB, Golueke CG, Kellen WR (1957) Algae in waste treatment. Sew Ind Wastes 29:437-455

Otero A, Vincenzini M (2003) Extracellular polysaccharide synthesis by Nostoc strains as affected by $\mathrm{N}$ source and light intensity. J Biotechnol 102:143-152

Panda D, DeLuca K, Williams D, Jordan MA, Wilson SL (1998) Antiproliferative mechanism of action of cryptophycin-52: kinetic stabilization of microtubule dynamics by high-affinity binding to microtubule ends. Proc Natl Acad Sci 95:9313-9318

Patzek T, Pimentel D (2005) Is ethanol from veggies a waste of fossil energy sources. Nat Resour Res 163(9):84-85

Phang SM, Miah MS, Yeoh BG, Hashim MA (2000) Spirulina cultivation in digested sago starch factory wastewater. J Appl Phycol 12(3):395-400

Phlips EJ, Mitsui A (1983) Role of light intensity and temperature in the regulation of hydrogen photoproduction by the marine cyanobacterium Oscillatoria sp. Strain Miami BG7. Appl Environ Microbiol 45:1212-1220

Piccardi R, Materassi R, Tredici M (1999) Algae and human affairs in the 21st century (Abstr Int Conf Appl Algol). Universita degli Studi di Firenze, Firenze

Ploutno A, Carmeli S (2005) Banyasin A and banyasides A and B, three novel modified peptides from a water bloom of the cyanobacterium Nostoc sp. Tetrahedron 61:575-583

Poelman E, De Pauw N, Jeurissen B (1997) Potential of electrolytic flocculation for recovery of micro-algae. Resour Conserv Recycl 19(1):1-10. doi:10.1016/S0921-3449(96)01156-1

Prakash J, Pushparaj B, Carlozzi P, Torzillo G, Montaini E, Materassi R (1997) Microalgal biomass drying by a simple solar device. Int J Sol Energy 18:303-311

Pulz O (2001) Photobioreactors: production systems for phototrophic microorganisms. Appl Microbiol Biotechnol 57(3):287-293

Pulz O, Gross W (2004) Valuable products from biotechnology of microalgae. Appl Microbiol Biotechnol 65:635-648. doi:10.1007/ s00253-004-1647-x

Rabinowitch EI (1951) Photosynthesis and related processes, vol. II, part I. Interscience, New York, p 966

Radmer RJ (1996) Algal diversity and commercial algal products. Biosci 46:263-270

Ragauskas AJ, Charlotte KW, Brian HD, George B, John C, Charles AE, William JF, Jason PH, David JL, Charles LL, Jonathan RM, Richard M, Richard T, Timothy T (2006) The path forward for biofuels and biomaterials. Science 311:484 489

Ramchandran S, Mitsui A (1984) Recycling of hydrogen photoproduction system using an immobilized marine blue green algae 
Oscillatoria sp. Miami BG7, solar energy and seawater, VII International Biotechnol Symp, pp. 183-184

Ran CQ, Chen ZA, Zhang W, Yu XJ, Jin MF (2006) Characterization of photobiological hydrogen production by several marine green algae. Wuhan Ligong Daxue Xuebao 28(2):258-263

Ranga RA, Dayananda C, Sarada R, Shamala TR, Ravishankar GA (2007) Effect of salinity on growth of green alga Botryococcus braunii and its constituents. Bioresour Technol 98:560-564

Ratledge C (1993) Single cell oils - have they a biotechnological future? Trends Biotechnol 11:278-284

Ratledge C (2004) Fatty acid biosynthesis in microorganisms being used for single cell oil production. Biochimie 86:807-815

Ratledge C, Wynn JP (2002) The biochemistry and molecular biology of lipid accumulation in oleaginous microorganisms. Adv Appl Microbiol 51:1-51

Remacle C, Cardol P, Coosemans N, Gaisne M, Bonnefoy N (2006) High-efficiency biolistic transformation of Chlamydomonas mitochondria can be used to insert mutations in complex I genes. Proc Natl Acad Sci USA 103:4771-4776

Richmond A (1987) The challenge confronting industrial microagriculture: high photosynthetic efficiency in large-scale reactors. Hydrobiologia 151:17-121

Richmond A (1999) Physiological principles and modes of cultivation in mass production of photoautotrophic microalgae. In: Cohen Z (ed) Chemicals from microalgae. Taylor and Francis Group, New York, pp 353-386

Richmond A (2000) Microalgal biotechnology at the turn of the millennium: a personal view. J Appl Phycol 12(3-5):441-451

Richmond A (2004) Principles for attaining maximal microalgal productivity in photobioreactors: an overview. Hydrobiologia $512: 33-37$

Riekhof WR, Sears BB, Benning C (2005) Annotation of genes involved in glycerolipid biosynthesis in Chlamydomonas reinhardtii: discovery of the betaine lipid synthase BTA1Cr. Eukaryot Cell 4:242-252

Rinzema A, van Lier J, Lettinga G (1988) Sodium inhibition of acetoclastic methanogens in granular sludge from a UASB reactor. Enzyme Microb Technol 10:24-32

Roessler PG (1990) Environmental control of glycerolipid metabolism in microalgae: commercial implications and future research directions. J Phycol 26:393-399. doi:10.1111/j.00223646.1990.00393.x

Roman RB, Alvarez-Pez JM, Acien Fernandez FG, Molina Grima E (2002) Recovery of pure B-phycoerythrin from the microalga Porphyridium cruentum. J Biotechnol 93:73-85

Running JA, Severson DK, Schneider KJ (2002) Extracellular production of L- ascorbic acid by Chlorella protothecoides, Prototheca species, and mutants of $P$. moriformis during aerobic culturing at low $\mathrm{pH}$. J Ind Microbiol Biotech 29:93-98

$\mathrm{S}$ and $\mathrm{T}$ (2003) The addition of ethanol from wheat to GHGenius, S and T Consultants, Delta, BC January, 2003.

Samson R, LeDuy A (1986) Detailed study of anaerobic digestion of Spirulina maxima algae biomass. Biotechnol Bioeng 28:10141023

Sanchez C (2009) Lignocellulosic residues: biodegradation and bioconversion by fungi. Biotechnol Adv 27:185-194

Sanchez MA, Contreras GA, Garcia CF, Molina GE, Chisti Y (1999) Comparative evaluation of compact photobioreactors for large scale monoculture of microalgae. J Biotechnol 70:249-270

Sawayama S, Inoue S, Dote Y, Yokoyama SY (1995) $\mathrm{CO}_{2}$ fixation and oil production through microalga. Energy Convers Manag 36:729-731

Schenk PM, Thomas-Hall SR, Stephens E, Marx UC, Mussgnug JH, Posten C, Kruse O, Hankamer B (2008) Second generation biofuels: high-efficiency microalgae for biodiesel production. Bioenergy Res 1:20-43. doi:10.1007/s12155-008-9008-8
Schmitz O, Boison G, Hilscher R, Hundeshagen B, Zimmer W, Lottspeich F, Bothe H (1995) Molecular biological analysis of a bidirectional hydrogenase from cyanobacteria. Eur J Biochem 233:266-276

Schonfeld M, Rahat M, Neumann J (1973) Photosynthetic reactions in the marine alga Codium vermilara. Plant Physiol 52:283-287

Schwartz J, Shklar G (1987) Regression of experimental hamster cancer by beta carotene and algae extracts. J Oral Maxillofac Surg 45:510-515

Schwartz JL, Sklar G, Reid S, Trickler D (1988) Prevention of experimental oral cancer by extracts of Spirulina-Dunaliella algae. Nutr Cancer 11:127-134

Serebryakova LT, Sheremetieva ME, Lindblad P (2000) $\mathrm{H}_{2}$-uptake and evolution in the unicellular cyanobacterium Chroococcidiopsis thermalis CALU 758. Plant Physiol Biochem 38:525-530

Servel MO, Claire C, Derrien A, Coiffard L, De Roeck-Holtzhauer Y (1994) Fatty acid composition of some marine microalgae. Phytochemistry 36:691-693

Sheehan J, Dunahay T, Benemann JR, Roessler P (1998) A look back at the US Department of Energy's aquatic species programBiodiesel from algae (Contract No. DE-AC36-83CH10093), The renewable energy laboratory, Golden, CO. Prepared for: Office of Fuels Development, US Department of Energy

Shelef G, Sukenik A, Green M (1984) Microalgae harvesting and processing: a literature review (SERI/STR-231-2396). Technion Research and Development Foundation Ltd., Haifa, pp 1-71

Shi XM, Jiang Y, Chen F (2002) High-yield production of lutein by the green microalga Chlorella protothecoides in heterotrophic fedbatch culture. Biotechnol Prog 18:723-727

Shi J, Podola B, Melkonian M (2007) Removal of nitrogen and phosphorus from wastewater using microalgae immobilized on twin layers: an experimental study. J Appl Phycol 19:417-423

Sialve B, Bernet N, Bernard O (2009) Anaerobic digestion of microalgae as a necessary step to make microalgal biodiesel sustainable. Biotechnol Adv. doi:10.1016/j.biotechadv.2009.03.001

Singh NK, Dhar DW (2006) Sewage effluent: a potential nutrient source for microalgae. Pro Ind Natn Sci Acad 72:113-120

Singh NK, Dhar DW (2007) Nitrogen and phosphorous scavenging potential in microalgae. Ind J Biotechnol 6:52-56, IPC code: Int Cl. $8 \mathrm{C} 02 \mathrm{~F} 3 / 32$

Solovchenko AE, Khozin-Goldberg I, Cohen Z, Merzlyak MN (2009) Carotenoid-to-chlorophyll ratio as a proxy for assay of total fatty acids and arachidonic acid content in the green microalga Parietochloris incise. J Appl Phycol 29:361-366

Speece RE (1996) Anaerobic biotechnology for industrial wastewaters. Archae, Nashville

Spolaore P, Joannis-Cassan C, Duran E, Isambert A (2006) Commercial applications of microalgae. J Biosci Bioeng 101(2):87-96. doi:10.1263/jbb.101.87

Sukenik A, Carmeli Y (1990) Lipid synthesis and fatty acid composition in Nannochloropsis sp. (Eustigmatophyceae) grown in a light-dark cycle. J Phycol 26:463-469. doi:10.1111/j.00223646.1990.00463.x

Sukenik A, Carmeli Y, Berner T (1989) Regulation of fatty acid composition by irradiance level in the eustigmatophyte Nannochloropsis sp. J Phycol 25:686-692. doi:10.1111/j.00223646.1989.00686.x

Sun Y, Yang Z, Gao X, Li Q, Zhang Q, Xu Z (2005) Expression of foreign genes in Dunaliella by electroporation. Mol Biotechnol 30:185-192

Survase SA, Bajaj IB, Singhal RS (2006) Biotechnological production of vitamins. Food Technol Biotechnol 44:381-396

Sveshnikov DA, Sveshnikova NV, Rao KK, Hall DO (1997) Hydrogen metabolism of mutant forms of Anabaena variabilis in continuous cultures and under nutritional stress. FEBS Microbiol Lett 147:297-301 
Takagi M, Karseno YT (2006) Effect of salt concentration on intracellular accumulation of lipids and triacylglyceride in marine microalgae Dunaliella cells. J Biosci Bioeng 101:223-226

Tamagnini P, Axelsson R, Lindberg P, Oxelfelt F, Wunschiers R, Lindblad P (2002) Hydrogenases and hydrogen metabolism of cyanobacteria. Microbiol Mol Biol Rev 66:1-20. doi:10.1128/ MMBR.66.1.1-20.2002

Tanaka S, Suda Y, Ikeda K, Ono M, Miyasaka H, Watanabe M, Sasaki $\mathrm{K}$, Hirata K (2007) A novel gene with antisalt and anticadmium stress activities from a halotolerant marine green alga Chlamydomonas sp. W80. FEMS Microbiol Lett 271:48-52

Tilton RC, Murphy J, Dixon JK (1972) The flocculation of algae with synthetic polymeric flocculants. Water Res 6:155-164

Tokuda H, Nishino H, Shirahashi H, Murakami N, Nagatsu A, Sakakibara J (1996) Inhibition of 12-O-tetradecanoylphorbol-13acetate promoted mouse skin papilloma by digalactosyl diacylglycerols from the freshwater cyanobacterium Phormidium tenue. Cancer Lett 104:91-96

Toreillo G, Pushparaj B, Masojidek J, Vonshak A (2003) Biological constraints in algal biotechnology. Biotechnol Bioprocess Eng 8:338-348

Tredici MR, Zittelli GC (1998) Efficiency of sunlight utilization: tubular versus flat photobioreactors. Biotechnol Bioeng 57 (2): 187-197

Tsygankov AA, Serebryakova LT, Rao KK, Hall DO (1998) Acetylene reduction and hydrogen photoproduction by wild type and mutant strains of Anabaena at different $\mathrm{CO}_{2}$ and $\mathrm{O}_{2}$ concentrations. FEMS Microbiol Lett 167:13-17

Ugwu CU, Ogbonna JC, Tanaka H (2005) Characterization of light utilization and biomass yields of Chlorella sorokiniana in inclined outdoor tubular photobioreactors equipped with static mixers. Process Biochem 40(11):3406-3411

Ugwu CU, Aoyagi H, Uchiyama H (2007) Influence of irradiance, dissolved oxygen concentration, and temperature on the growth of Chlorella sorokiniana. Photosynthetica 45(2):309-311

Vadiraja BB, Gaikwad NW, Madyastha KM (1998) Hepatoprotective effect of C-phycocyanin: protection for carbon tetrachloride and $\mathrm{R}-(+)$-polygene-mediated hepatotoxicity in rats. Biochem Biophys Res Commun 249(2):428-431

Valencia I, Ansorena D, Astiasaran I (2007) Development of dry fermented sausages rich in dicosahexanoic acid with oil from the microalgae Schizochytrium sp.: influence on nutritional properties, sensorial quality and oxidation stability. Food Chem 104:1087-1096

Van der Oost J, Bulthuis BA, Feitz S, Krab K, Kraayenhof R (1989) Fermentation metabolism of the unicellular cyanobacterium Cyanothece PCC 7822. Arch Microbiol 152:415-419

Van Gerpen J (2005) Biodiesel processing and production. Fuel Process Technol 86:1097-1107

Vandenbroucke M, Largeau C (2007) Kerogen origin, evolution and structure. Org Geochem 38:719-833

Vazquez-Duhalt R, Arredondo-Vega B (1991a) Halo-adaptation of the green alga Botryococcus braunii. Phytochem 30:2919-2925

Vazquez-Duhalt R, Arredondo-Vega B (1991b) Oil production from microalgae under saline stress, biomass for energy and industry, 5th EC Conference, Vol.1: Policy, Environment, Production and Harvesting

VDI (2004) Vergarung organischer Stoffe, In: Verein Deutscher Ingenieure Guidelines 2004, Guideline VDI 4630, Dusseldorf, Germany
Vlad M, Bordas E, Caseanu E, Uza G, Creteanu E, Polinicenco C (1995) Effect of cuprofilin on experimental athero-sclerosis. Biol Trace Elem Res 48(1):99-109

Vonshak A, Torzillo G, Masojidek J, Boussiba S (2001) Sub-optimal morning temperature induces photoinhibition in dense outdoor cultures of the alga Monodus subterraneus (Eustigmatophyta). Plant Cell Environ 24(10):1113-1118

Walker TL, Purton S, Becker DK, Collet C (2005) Microalgae as bioreactors. Plant Cell Rep 24:629-641

Wang Z, Pan Y, Dong T, Zhu X, Kan T, Yuan L, Torimoto Y, Sadakata M, Li Q (2007) Production of hydrogen from catalytic steam reforming of bio-oil using C12A7-O-based catalysts. Appl Catal A 320:24-34

Weissman JC, Goebel RP (1985) Production of liquid fuels and chemicals by microalgae (Report SERI/STR-231-2649, Subcontract No. XK-3-03136, Contract No. DE-AC02-83CH10093), Solar Energy Research Institute, Golden, CO. Prepared for US Department of Energy, pp. 116

Weissman JC, Goebel RP (1987) Design and analysis of microalgal open pond systems for the purpose of producing fuels (Report SERI/STR-231-2840) (Contract No. DE-AC02-83CH10093, subcontract No. XK-3-03153-1). Solar Energy Research Institute, Golden CO. Prepared for US Department of Energy, pp. 214

Weissman JC, Tillett DM (1992) Aquatic Species Project Report; NREL/MP-232-4174, Brown LM, Sprague S (Eds.) National renewable energy laboratory, Golden CO, pp. 41-58.

Wen ZY, Chen F (2000) Production potential of eicosapentaenoic acid by the diatom Nitzschia laevis. Biotechnol Lett 22(9):727733

Wen WG, Chen F (2003) Heterotrophic production of eicosapentaenoic acid by microalgae. Biotechnol Adv 21:273-294

Yang H, Lee E, Kim H (1997) Spirulina platensis inhibits anaphylactic reaction. Life Sci 61:1237-1244

Yang XW, Wynder C, Doughty ML, Heintz N (1999) BAC-mediated gene-dosage analysis reveals a role for Zipro1 (Ru49/Zfp38) in progenitor cell proliferation in cerebellum and skin. Nat Genet 22:327-335

Yang C, Hua Q, Shimizu K (2000) Energetics and carbon metabolism during growth of microalgal cells under photoautotrophic, mixotrophic and cyclic light-autotrophic/dark-heterotrophic conditions. Biochem Eng J 6:87-102

Yen HW, Brune DE (2007) Anaerobic co-digestion of algal sludge and waste paper to produce methane. Bioresour Technol 98:130-134

Yu H, Jia S, Dai Y (2009) Growth characteristics of the cyanobacterium Nostoc flagelliforme in photoautotrophic, mixotrophic and heterotrophic cultivation. J Appl Phycol 21(1):127-133. doi:10.1007/s10811-008-9341-5

Zeiler KG, Heacox DA, Toon S, Kadam K, Brown LM (1995) The use of microalgae for assimilation and utilization of carbon dioxide from fossil fuel-fired power plant flue gas. Energy Convers Manag 36:707-712

Zhu Y, Lee YY, Elander RT (2007) Conversion of aqueous ammoniatreated corn stover to lactic acid by simultaneous saccharification and cofermentation. Appl Biochem Biotechnol 137-140(112):721-738. doi:10.1007/s12010-007-9092-9

Zittelli CG, Rodolfi L, Biondi N, Tredici MR (2006) Productivity and photosynthetic efficiency of outdoor cultures of Tetraselmis suecica in annular columns. Aquaculture 261:932-943 